\title{
Mineralogy and Geochemistry of Seabed Sediments of the Chiloé-Taitao Area, Southern Chile, and Implications for Ore Deposits
}

\author{
Marisol Pérez ${ }^{1,2}$, Marcelo García ${ }^{1,2, *(D)}$, Brian Townley ${ }^{1,2}$ and Katja Deckart ${ }^{1,2}$ (D) \\ 1 Departamento de Geología, Universidad de Chile, Santiago 8370450, Chile; \\ marisol.perez.h@ing.uchile.cl (M.P.); btownley@ing.uchile.cl (B.T.); kdeckart@ing.uchile.cl (K.D.) \\ 2 Advanced Mining Technology Center (AMTC), Universidad de Chile, Santiago 8370451, Chile \\ * Correspondence: mgarciagodoy@ing.uchile.cl
}

Citation: Pérez, M.; García, M.; Townley, B.; Deckart, K. Mineralogy and Geochemistry of Seabed

Sediments of the Chiloé-Taitao Area, Southern Chile, and Implications for Ore Deposits. Minerals 2021, 11, 903. https://doi.org/10.3390/min11080903

Academic Editors: Shiki Machida and Kentaro Nakamura

Received: 5 January 2021

Accepted: 22 June 2021

Published: 21 August 2021

Publisher's Note: MDPI stays neutral with regard to jurisdictional claims in published maps and institutional affiliations.

Copyright: (c) 2021 by the authors. Licensee MDPI, Basel, Switzerland. This article is an open access article distributed under the terms and conditions of the Creative Commons Attribution (CC BY) license (https:/ / creativecommons.org/licenses/by/ $4.0 /)$.

\begin{abstract}
The oceanic seabed contains a variety of mineral resources related exclusively to submarine environments. Limited information has been documented for the seabed offshore of Chile, which is particularly interesting due to its geodynamic context and large area. Mineralogical and geochemical analyses of 16 sites within the Chiloé-Taitao area, from 83 to $3388 \mathrm{~m}$ in depth, were carried out. The most abundant minerals are quartz, feldspars, pyroxenes, amphiboles, epidote, and biotite, with lower quantities of zircon, white mica, olivine, pyrite, magnetite, ilmenite, and hematite. Framboidal pyrites are mainly present at $>900 \mathrm{~m}$ depth, and could be associated with methane hydrates, which have been reported in the area and its surroundings. Tenorite, sphalerite, tennantite, cordierite, birnessite, and tellurobismuthite were revealed by XRD analysis at low concentrations but at many sites. Birnessite, a Fe-Mn nodule-forming mineral, was widely detected, and Pearson correlations showed elemental associations related to the presence of Mn oxides. Samples did not evidence Fe-Mn nodules, probably due to the redox and depth conditions. Nonetheless, it is probable that to the west, polymetallic nodules are present in deeper zones. In the southern part of the area, reflective grains were identified, with up to $58.3 \mathrm{wt} . \% \mathrm{Cu}$; these grains might be derived from the continent or formed by in situ diagenetic precipitation.
\end{abstract}

Keywords: Chilean offshore; framboidal pyrite; Fe-Mn nodule; copper; depth and redox conditions

\section{Introduction}

The exploration of the ocean floor has been increasing due to the presence of mineral resources (e.g., [1-4]). The Pacific Ocean basin has important polymetallic deposits, including Fe-Mn nodules and crusts and volcanogenetic sulphides, as well methane hydrates, but its investigation at high and intermediate latitudes is still incomplete [3,5]. Oceanic ridges and areas near the coast, which record Pleistocene glaciations, are key to the study of these mineral occurrences [6,7]. In Chile, the exclusive economic zone (EEZ) covers an area of approximately five times the continental territory and very limited information about its mineral resources is available (e.g., [8]). Few samples have been taken and insufficient mineralogical and geochemical analyses made. Off the shore of southern Chile, between Chiloé Island and Taitao peninsula (from 41.3 to $45.6^{\circ} \mathrm{S}$ ), the scarce record of submarine mineral resources corresponds to some samples of polymetallic nodules, near the trench $[9,10]$, and methane hydrates, at the Chile triple junction west of Taitao [11-13]. Gas hydrates have been inferred and extended throught seismic studies west of Los Chonos Archipelago [14] and to the southwest of Chiloé Island [15]. Investigations of marine sediments south of the area at Magallanes revealed heavy metal anomalies, highlighting platinum concentrations up to $70 \mathrm{ppb}$ at $334 \mathrm{~m}$ depth [16].

On the continental part of the study area, there are important gold and heavy-mineral placers in littoral and glacial quaternary sediments [17-19]. Specifically, on Chiloé, the 
beach deposits have gold concentrations up to $15 \mathrm{~g} / \mathrm{m}^{3}$, including Cucao and Carelmapu beaches [18]. While the glaciers were stopped by the Coastal Cordillera to the north of the Chiloé Island, the ice southward would have excavated channels down to the continental shelf and deposited its sediments [20]. The greatest material transport occurs during the lowering of the sea level in glacial periods, when continental rivers connect to submarine canyons and terrigenous material can be effectively transported to the deep sea [21]. This, together with the ability of ocean currents, tides, and waves to transport detrital material into the deep sea, suggests an extension of the littoral placers towards the sea bottom. Furthermore, in the continental region, gold, silver, zinc, and copper deposits are related to metamorphic and intrusive rocks, and could be a source for submarine deposits [22-24].

The present study sought to add mineralogical and geochemical information about seabed sediments and to detect probable abnormal concentrations of heavy minerals, base metals, polymetallic nodules, and/or methane hydrates. The origin of metals in sediments was expected to be related to the deposits of the continental area and/or the hydrothermal activity of the Chile Rise. In particular, we hypothesized that the heavy mineral concentrations would be larger in the submarine canyons than on the continental shelf.

\section{Geological Setting}

The submarine study area is located in an active subduction zone, and consists mainly of the platform and talus, between 0 and $4000 \mathrm{~m}$ in depth, which contain local basins and are cut by E-W and NW-SE submarine canyons (Figure 1). The terrigenous sedimentary supply allows the formation of an active accretionary prism that, together with the Paleozoic prism, is expressed as an irregular relief on the edge of the South American plate between 1000 and $4000 \mathrm{~m}$ in depth [25]. Four submarine canyons have been defined from north to south, Chacao and Cucao west of Chiloé Island [20] and Simpson and Darwin west of Chonos Archipelago [25,26]. The trench has a maximum depth of about $6000 \mathrm{~m}$, which decreases progressively southwards until the triple junction of the Nazca-Antarctic-South American plates, west of Taitao, where the accretionary prism disappears [25].

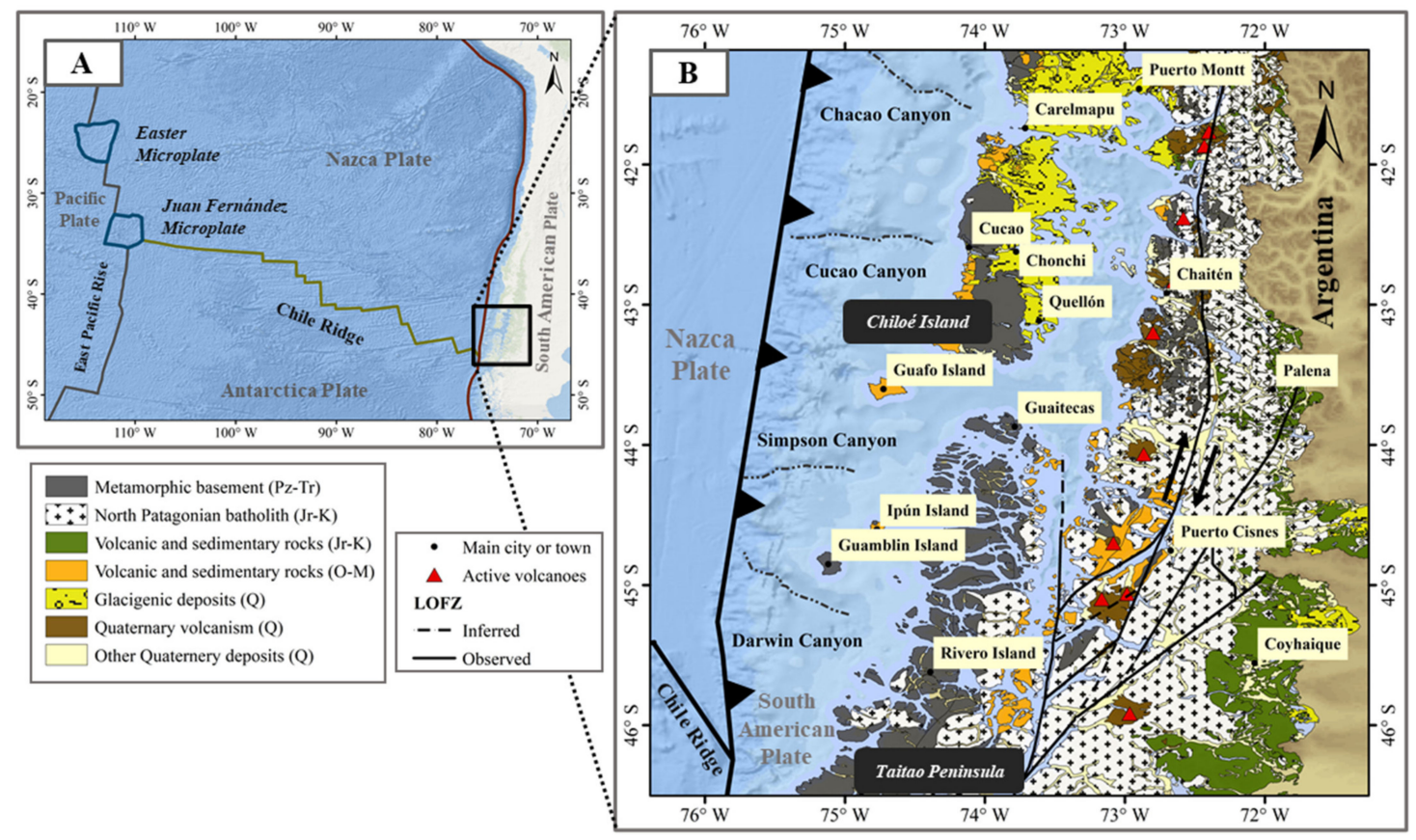

Figure 1. (A): Main tectonic features and boundaries of the Nazca, Antarctica, and East Pacific plates [27]. (B): Geological map of the study the area. Geology taken from Sernageomin (2003). “Oceans Basemap" developed by Esri (2010).

The Chile Ridge is a positive topographic feature with a NNW-trending central axis, characterized by a rugged relief and a near absence of sediment cover [28,29] (Figure 1). 
This oceanic spreading center extends from the junction of the Pacific, Antarctic, and Nazca plates at the Juan Fernandez microplate to the Taitao triple junction, where is subducted beneath the active South American margin [30-32].

The continental area comprises the geomorphological domains of the Coastal Cordillera, the intermediate depression, and Principal Cordillera, which are distributed between insular and continental areas from west to east. The basement unit to the north of $44^{\circ} \mathrm{S}$ is the Paleozoic-Triassic Bahia Mansa Metamorphic Complex, which has been interpreted as an accretion-subduction complex [33-36]. Similarly, the Los Chonos Metamorphic Complex, of the Late Triassic-Early Jurassic age, extends from 44 to $46^{\circ} \mathrm{S}$ and in its eastern edge is intruded by the North Patagonian batholith [37,38] (Figure 1).

Late Jurassic-Cretaceous stratigraphy is represented by the rhyolitic-andesitic volcanics of the Ibáñez and Divisadero Formations, in addition to the sedimentary units of the Coyhaique Group [39-42]. Plutonic rocks correspond to the Mesozoic-Cenozoic North Patagonian batholith, which is located in the eastern part of Coastal Cordillera and in the Principal Cordillera, where Quaternary volcanism is also manifested [37,43]. In the Peninsular area and longitudinal valley, Eocene to Miocene sedimentary and volcanic rocks of marine origin are exposed [36,44,45]. Furthermore, glaciogenic Pleistocene deposits have been recognized [42,46]. The major strike-slip Liquiñe-Ofqui fault system is right lateral and trench-parallel, recognized for more than $1200 \mathrm{~km}$, between $38^{\circ} \mathrm{S}$ and the Taitao triple junction at $46^{\circ} \mathrm{S}[47-50]$.

Economic mineral occurrences in the continental area consist of Late Jurassic polymetallic vein and skarn deposits, and Early Cretaceous Zn-Pb skarn, hydrothermal polymetallic vein, and epithermal precious metal deposits [22,23,51] (Figure 2). Gold placers are the principal ore deposits in the peninsular areas and are accompanied by moraine, beach, glacio-fluvial, and glacio-lacustrine deposits, which are related to erosion and transport toward lower altitudes by the Pleistocene glaciations $[17,18]$. The Principal Cordillera have been identified as the major source of the detrital gold [19]. However, north of the study area, at the latitude of Valdivia, the metamorphic basement has been suggested to be the source of the gold placers in the Madre de Dios district [17,18].

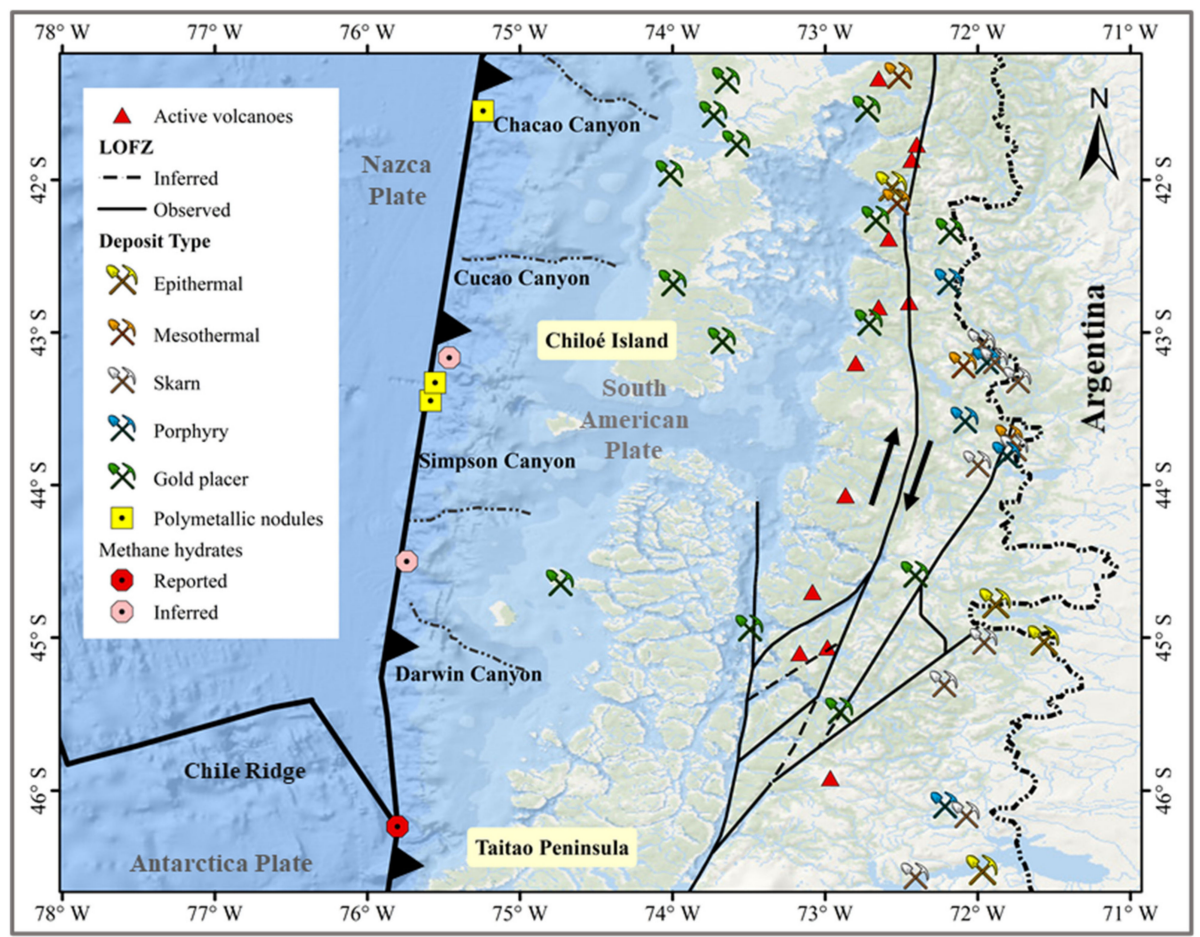

Figure 2. Economic geology of the study area $[8,12,14,15,23,24]$. “Oceans Basemap" developed by Esri (2010). 


\section{Materials and Methods}

Sixteen samples were collected from the Chilean Navy scientific vessel "Cabo de Hornos", from which geophysical survey necessary for determining sample points was also gathered. Multibeam bathymetry, used to map the seabed, was acquired through two sonars, EM 122 and EM 710. Monochannel seismic acquisition was undertaken by the SBP 120 Sub-bottom profiler, an acoustic device that images the first sediment layers below the seafloor. The samples were collected using a Van Veen grab sampler with a capacity of $59 \mathrm{~L}$, and a box corer with a capacity of $169 \mathrm{~L}$. Immediately after the sampling, in the water-saturated sediment, $\mathrm{pH}$, redox, and temperature values were measured using a MultiLine ${ }^{\circledR M u l t i} 3620$ IDS multiparameter portable meter. After each sampling, the equipment was carefully cleaned to prevent contamination between samples.

The samples were treated and mineralogically analyzed in the Laboratories of the Department of Geology and Department of Physics at the University of Chile (http:// ingenieria.uchile.cl/investigacion/presentacion/laboratorios). The samples were kept refrigerated until processing. In the first instance, the sediments were dried in an oven at temperatures ranging from 37 to $40{ }^{\circ} \mathrm{C}$, and subsequently were divided, by manual quartering, into subsamples for granulometric, mineralogical, and geochemical analysis (Table 1). [52,53]

Table 1. Summary of subsample types and analyses. FBM: free of biogenic material.

\begin{tabular}{|c|c|c|c|c|c|c|}
\hline Analyses & $\begin{array}{l}\text { Granulometry } \\
\quad \text { (Laser) }\end{array}$ & $\begin{array}{c}\text { Optical } \\
\text { MICROSCOPE } \\
(>75 \mu \mathrm{m})\end{array}$ & SEM-EDS & $\underset{(<75 \mu \mathrm{m})}{\text { XRD }}$ & ICP-ES/MS & Fire Assay \\
\hline Subsample type & $\begin{array}{l}\text { Whole sediment } \\
\text { (FBM) }\end{array}$ & $\begin{array}{c}\text { Whole sediment } \\
\text { (FBM) } \\
\text { Heavy mineral } \\
\text { concentrate }\end{array}$ & $\begin{array}{l}\text { Heavy mineral } \\
\text { concentrate } \\
(>75 \mu \mathrm{m})\end{array}$ & $\begin{array}{l}\text { Whole sediment } \\
\text { (FBM) } \\
\text { Heavy mineral } \\
\text { concentrate }\end{array}$ & Whole sediment & Whole sediment \\
\hline
\end{tabular}

The granulometric characterization was carried out via a combination of wet sieving and laser granulometry from which textural and granulometric classifications were determined [54]. The fractions above $1 \mathrm{~mm}$ were sieved with $2 \mathrm{~mm}$ and $3 \mathrm{~mm}$ mesh sieves, and were later weighed and the mass values converted into volume according to a standard density of $2.67 \mathrm{~g} / \mathrm{cm}^{3}$. Fractions of particle size under $1 \mathrm{~mm}$ were determined using a Malvern Mastersizer $2000^{\circledR}$ laser diffractometer.

Mineralogy was analyzed using microscopy and X-ray diffraction (XRD), and some selected minerals were further analyzed for chemical composition in the electron microscopy and microanalysis laboratory (SEM-EDS). The samples were sifted. The coarse fraction (above $75 \mu \mathrm{m}$ ) was studied with stereoscopic and optical microscopy, through transparentpolished thin sections; meanwhile, the finer fraction $(<75 \mu \mathrm{m})$ was pulverized (for assurance of finer granulometry) and examined using a Bruker D8 Advance X-ray diffractometer. The mineralogy of both fractions was studied from two subsample types: biogenic-materialfree whole sediment and heavy mineral concentrate (Table 1). The biogenic-material-free whole-sediment subsamples were subjected to standard procedures recommended by the Ocean Drilling Program (ODP) [52,53]. This allowed carbonate, organic matter, and biogenic silica to be removed and thus not to interfere with chemically stable inorganic material analysis. For these deletions, 10\% hydrochloric acid, 30\% hydrogen peroxide, and $1.5 \mathrm{M}$ sodium hydroxide were used at temperatures between $80^{\circ} \mathrm{C}$ and $85^{\circ} \mathrm{C}$. The subsamples of heavy mineral concentrates were obtained by using a vibrating Gemini table, magnetic separation, and heavy liquid bromoform, through which the particles denser than $2.8 \mathrm{~g} / \mathrm{cm}^{3}$ were separated.

For X-ray diffraction, specific reference standards and databases were used for determination of rock-forming and ore minerals. From the X-ray diffractograms, the mineral phases were identified using the DIFFRAC.EVA $\odot$ (version 2.1) and Match! $3 \odot$ commercial software (version 3.10.2.173). Furthermore, a Rietveld refinement was carried out using Match! 3 and Fullprof programs to calculate phase percentages. 
Geochemical whole-sediment data were obtained through ICP-ES and ICP-MS analysis for 41 elements at Bureau Veritas Minerals Laboratories. The procedure considered multi-acid digestion for sulfide and silicate ores. Additionally, $\mathrm{Au}$ and $\mathrm{Pt}$ concentrations were measured in 12 samples by ICP-ES after a lead collection fire assay fusion, with $2 \mathrm{ppb}$ and $3 \mathrm{ppb}$ detection limits, respectively. The precision and accuracy of the ICP analyses were monitored using high-sulfidation epithermal Ag-Cu-Au ore (OREAS 605) and copper ore (OREAS 927) from OREAS Reference Materials, while analytical precision for Au and Pt fire assays was controlled with Rocklabs reference material PD05. Likewise, four duplicate samples were inserted for quality control purposes. Univariate and multivariate data statistical treatments were done using ioGAS () software. The principal elemental associations were obtained using the Pearson's correlation matrix methodology, a tool widely used in regional geochemical studies, among other multivariate statistical analyses (e.g., $[23,55,56])$.

\section{Results}

Thirteen samples were collected with the grab sampler and three samples with the box corer, from water depths between 83 and $3388 \mathrm{~m}$ (Table 2). The samples were captured from submarine canyons, continental shelf, inner channels, and continental slope. Additionally, at seven predefined sampling points, the grab sampler and box corer did not collect sediment, and access south of Taitao Peninsula was impossible due to adverse weather conditions (Figure 3). In situ temperatures of sediment samples varied between 4.3 and $10.5^{\circ} \mathrm{C}$, and all samples that exceeded $10^{\circ} \mathrm{C}$ were extracted from the inner shelf areas (samples 13, 14, 15, and 16) (Table 2). In situ $\mathrm{pH}$ values ranged from 7.4 to 7.9. Redox potential was reduced (from -133.2 to $-9.37 \mathrm{mV}$ ), except for samples 10, 12, and 13, which indicated oxidizing environments (from 42.67 to $186.7 \mathrm{mV}$ ).

Table 2. General features of collected samples. * no measurements were recorded.

\begin{tabular}{|c|c|c|c|c|c|c|c|c|c|c|}
\hline Sample & Geomorphology & $\begin{array}{l}\text { Depth } \\
\text { (m) }\end{array}$ & $\begin{array}{c}\text { Lat. S } \\
\left({ }^{\circ}\right)\end{array}$ & $\begin{array}{c}\text { Lat. S } \\
\left({ }^{\prime}\right)\end{array}$ & $\begin{array}{c}\text { Long.W } \\
\left({ }^{\circ}\right)\end{array}$ & $\begin{array}{c}\text { Long.W } \\
\left(^{\prime}\right)\end{array}$ & $\begin{array}{l}\text { Weight } \\
\text { (kg) }\end{array}$ & $\mathrm{pH}$ & $\mathrm{T}^{\circ}\left({ }^{\circ} \mathrm{C}\right)$ & $\begin{array}{c}\text { Redox } \\
(\mathrm{mV})\end{array}$ \\
\hline 1 & Continental slope & 1071 & 41.00 & 31.06 & 74.00 & 49.86 & 23.7 & 7.89 & 8.50 & -42.37 \\
\hline 2 & Cucao canyon mouth & 1916 & 42.00 & 30.72 & 75.00 & 31.12 & 15.5 & 7.79 & 7.27 & -131.37 \\
\hline 3 & External continental shelf & 166 & 42.00 & 28.08 & 74.00 & 26.23 & 23.4 & 7.71 & 10.0 & -52.61 \\
\hline 4 & External continental shelf & 239 & 43.00 & 46.50 & 74.00 & 37.08 & 21.5 & 7.57 & 9.17 & -107.67 \\
\hline 5 & External continental shelf & 226 & 44.00 & 25.87 & 75.00 & 18.51 & 7.10 & 7.69 & 8.83 & -31.03 \\
\hline 6 & Simpson canyon bed & 917 & 44.00 & 11.36 & 74.00 & 59.50 & 18.5 & 7.66 & 7.10 & -72.10 \\
\hline 7 & Simpson canyon bed & 1070 & 44.00 & 7.96 & 75.00 & 4.89 & 23.5 & 7.73 & 5.80 & -112.77 \\
\hline 8 & Simpson canyon bed & 1619 & 44.00 & 10.82 & 75.00 & 22.48 & 25.6 & 7.83 & 4.30 & -115.87 \\
\hline 9 & Simpson canyon mouth & 3388 & 44.00 & 13.89 & 75.00 & 50.24 & 32.1 & 7.77 & 7.30 & -55.13 \\
\hline 10 & External continental shelf & 317 & 45.00 & 4.53 & 74.00 & 34.04 & 12.5 & 7.52 & 8.00 & 42.67 \\
\hline 11 & Darwin canyon mouth & 2952 & 44.00 & 45.25 & 75.00 & 44.98 & 31.6 & * & * & * \\
\hline 12 & External continental shelf & 134 & 45.00 & 27.93 & 75.00 & 3.98 & 9.9 & 7.43 & 9.63 & 147.47 \\
\hline 13 & Internal continental shelf & 83 & 45.00 & 22.43 & 73.00 & 37.92 & 30.2 & 7.63 & 10.2 & 186.70 \\
\hline 14 & Internal continental shelf & 273 & 44.00 & 11.81 & 73.00 & 25.24 & 20.3 & 7.56 & 10.03 & -133.20 \\
\hline 15 & Internal continental shelf & 97 & 43.00 & 27.75 & 73.00 & 25.76 & 10.8 & 7.86 & 10.13 & -9.37 \\
\hline 16 & Internal continental shelf & 298 & 41.00 & 59.36 & 73.00 & 14.13 & 20.8 & 7.46 & 10.50 & -80.53 \\
\hline
\end{tabular}

\subsection{Granulometry}

The results of the granulometric analysis are shown in Table 3, where fine fractions dominated with limited material in the gravel size range in three samples (samples 1, 13, and 15). In sample 1, a clast of $1.4 \mathrm{~cm}$ in size, mostly composed by quartz, was inconsistent with the rest of the muddy sediment. In the same way, in sample 15, gravel-sized material reached $0.01 \%$, in addition to a clast of approximately $10 \mathrm{~cm}$ that was not considered in the granulometric measurements. 


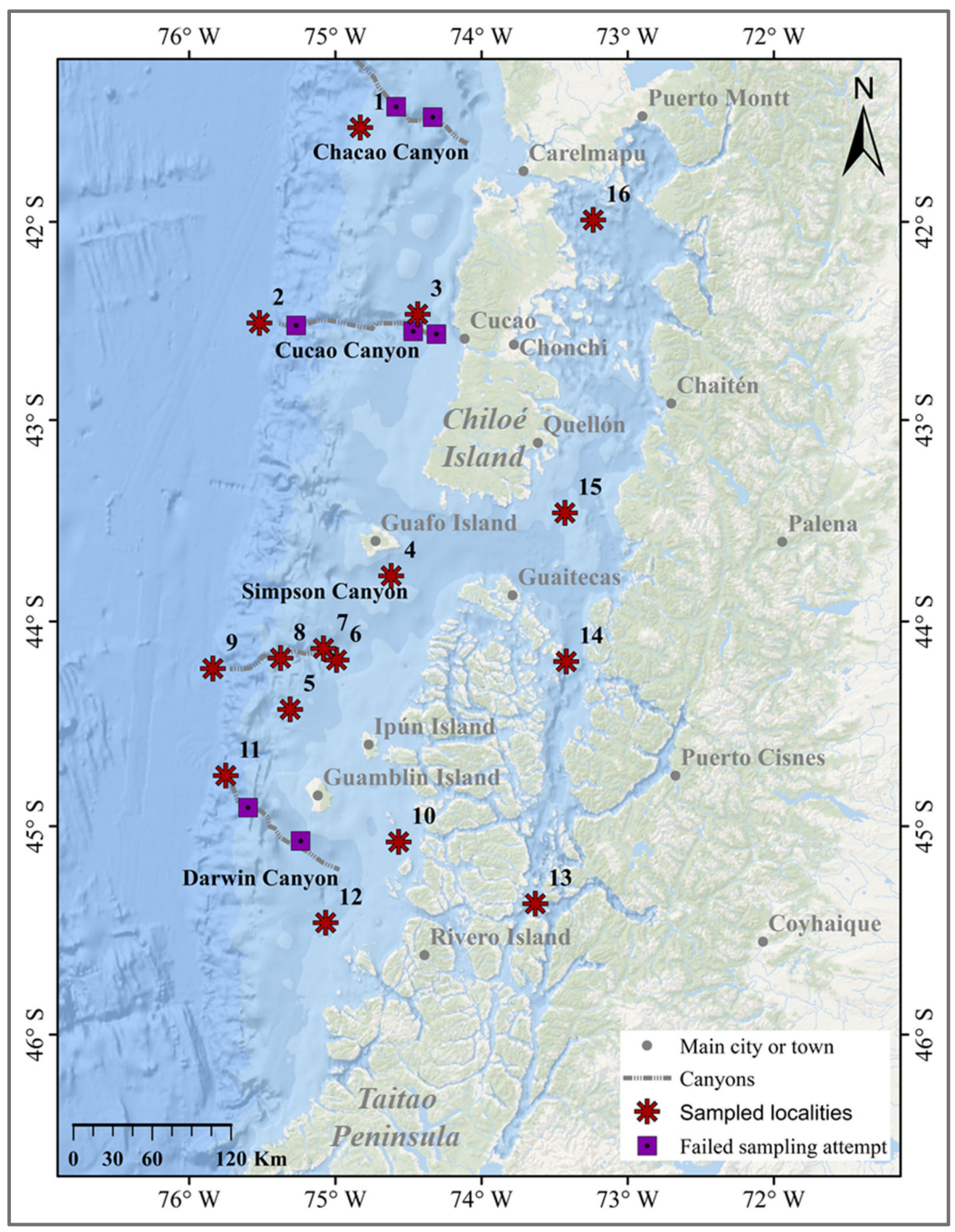

Figure 3. Sampled localities and failed attempts.

The textural classification, according to Folk (1974), indicated 10 samples of muds and 6 samples of sands (Figure 4A). Sandy muds represented $44 \%$ and were widely distributed in submarine canyons. These were followed by muddy sands, which constituted $26 \%$ and were restricted to the continental shelf south of Guafo Island (Figure 4B). Sands were limited to inner channels and coexisted with muds due to depth differences and horizontal water movements. The granulometric classification, for fractions lower than $2 \mathrm{~mm}$ (Folk, 1974), showed that within the mud fraction, a clear dominance of silty sediment with clay contents of about $10 \%$ existed (Figure 4C). Five of seven samples of sandy silt came from submarine canyons, while all samples of silty sand came from the continental shelf. Seabed morphology, marine currents, and river and wind dynamics can explain granulometric differences in similar settings. 
Table 3. Distribution of gravel, sand, mud, silt, and clay fractions. Granulometric and textural classifications according to Folk (1974).

\begin{tabular}{|c|c|c|c|c|c|c|c|}
\hline Samples & $\begin{array}{l}\text { Depth } \\
\text { (m) }\end{array}$ & $\begin{array}{c}\text { Gravel } \\
(\%)\end{array}$ & $\begin{array}{c}\text { Sand } \\
(\%)\end{array}$ & $\begin{array}{l}\text { Silt } \\
(\%)\end{array}$ & $\begin{array}{l}\text { Clay } \\
(\%)\end{array}$ & Textural Classification & $\begin{array}{c}\text { Granulometric } \\
\text { Classification }\end{array}$ \\
\hline 01 & 1071 & 0.0001 & 29.3 & 61.0 & 9.7 & Sandy Mud & Sandy Silt \\
\hline 02 & 1916 & 0 & 3.2 & 86.2 & 10.6 & Mud & Silt \\
\hline 03 & 166 & 0 & 44.2 & 52.2 & 3.7 & Sandy Mud & Sandy Silt \\
\hline 04 & 239 & 0 & 50.1 & 44.7 & 5.2 & Muddy Sand & Silty Sand \\
\hline 05 & 226 & 0 & 74.5 & 22.6 & 3.0 & Muddy Sand & Silty Sand \\
\hline 06 & 917 & 0 & 24.9 & 65.8 & 9.3 & Sandy Mud & Sandy Silt \\
\hline 07 & 1070 & 0 & 6.7 & 80.2 & 13.0 & Mud & Silt \\
\hline 08 & 1619 & 0 & 13.3 & 75.8 & 11.0 & Sandy Mud & Sandy Silt \\
\hline 09 & 3388 & 0 & 26.8 & 62.3 & 10.9 & Sandy Mud & Sandy Silt \\
\hline 10 & 317 & 0 & 57.5 & 38.5 & 4.1 & Muddy Sand & Silty Sand \\
\hline 11 & 2952 & 0 & 19.2 & 70.6 & 10.2 & Sandy Mud & Sandy Silt \\
\hline 12 & 134 & 0 & 87.5 & 10.9 & 1.6 & Muddy Sand & Silty Sand \\
\hline 13 & 83 & 0.00001 & 91.6 & 6.6 & 1.8 & Sand & Sand \\
\hline 14 & 273 & 0 & 3.0 & 81.9 & 15.2 & Mud & Silt \\
\hline 15 & 97 & 0.01 & 90.8 & 8.2 & 1.0 & Sand & Sand \\
\hline 16 & 298 & 0 & 12.1 & 74.6 & 13.3 & Sandy Mud & Sandy Silt \\
\hline
\end{tabular}
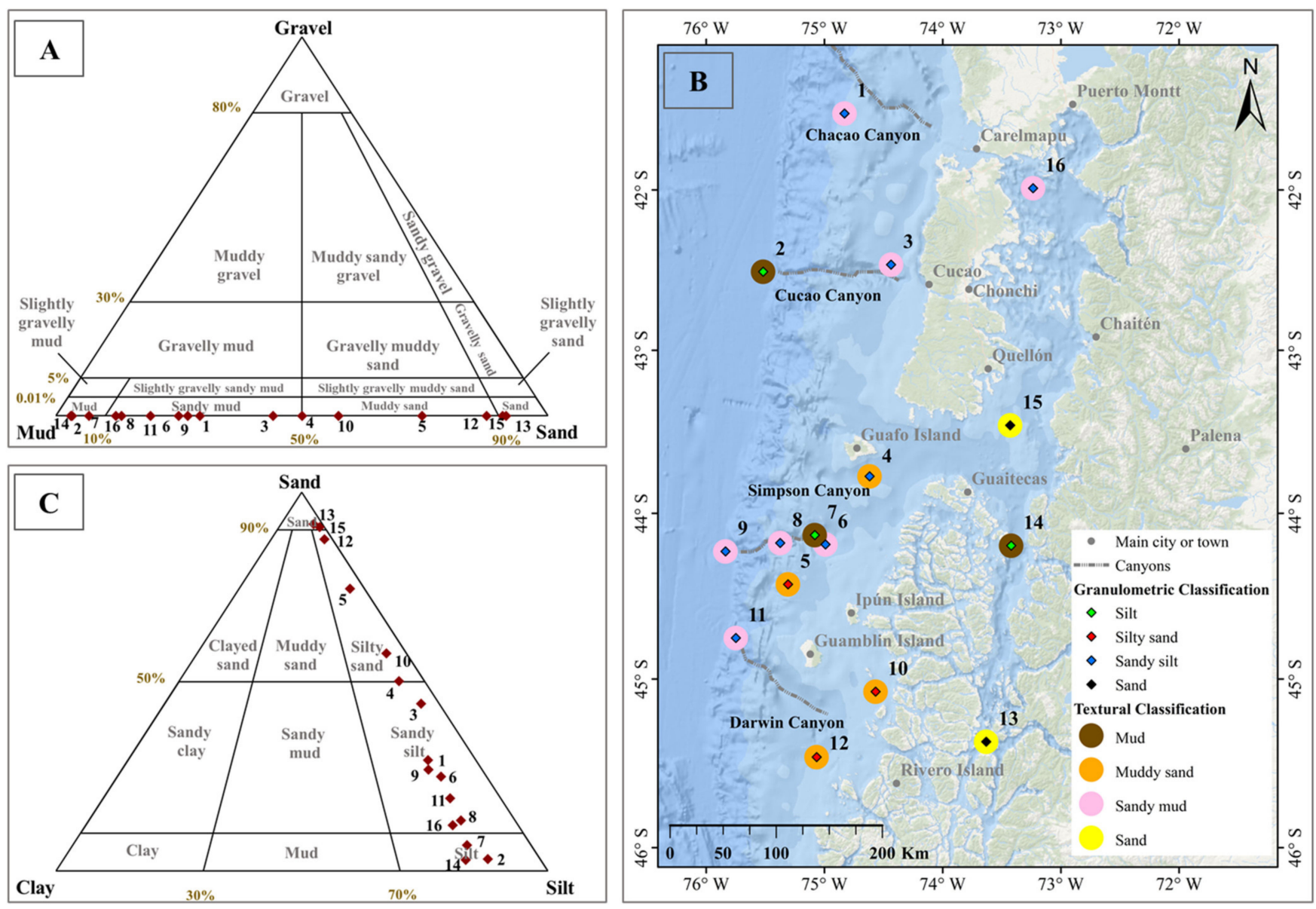

Figure 4. Granulometry results [54]. (A): Textural classification, (B): granulometric classification, and (C): distribution map of samples. 


\subsection{Mineralogy}

\subsubsection{Fractions Larger Than $75 \mu \mathrm{m}$}

Thirteen samples yielded coarse material from heavy mineral and biogenic-materialfree whole-sediment material concentrates, and were studied via optical microscopy. Two samples were submitted to SEM-EDS analysis. In biogenic-material-free wholesediment concentrates, a predominance of quartz and plagioclase was observed, and in a lesser proportion, but present in most samples, pyroxenes, amphiboles, epidote, and biotite; these were affected by chlorite replacement alteration at different levels. Other rock-forming minerals such as zircon, white mica, and K-feldspar were observed in low quantities; these were related to continental shelf zone samples. Likewise, the presence of olivine was mainly linked to inner channels, and was higher in the sands of samples 13 and 15. Pyrite, magnetite, hematite, and ilmenite were present in low proportions but in all samples. Lithic fragments were predominantly present at depths of less than $1000 \mathrm{~m}$. These were mainly of metamorphic and volcanic origin, and sedimentary in a lesser proportion; plutonic lithics were rare. Lithic fragments of volcanic origin were significant in samples near the coast.

In the heavy mineral concentrates, felsic minerals (quartz, feldspars, and with mica) were absent, and mafic and opaque minerals and lithic fragments are similar to the wholesediment concentrates. Pyrite was the most abundant opaque mineral and occurred in lithic fragments and isolated grains and as framboids. In thin sections of the heavy mineral concentrates, up to $5 \%$ of pyrite was estimated. In samples collected from the continental shelf, pyrite was observed within volcanic fragments and as individual angular grains. Framboidal pyrite mostly occurred in samples extracted from submarine canyons, between 917 and $3388 \mathrm{~m}$ depth, as well as in samples $3(166 \mathrm{~m})$ and $5(226 \mathrm{~m})$ from the external portion of the submarine continental shelf. Framboids were developed around cavities, particularly inside bioclasts such as foraminifera, algae, gastropods, ostracods, and echinoderms, and growing on mineral surfaces (Figure 5).
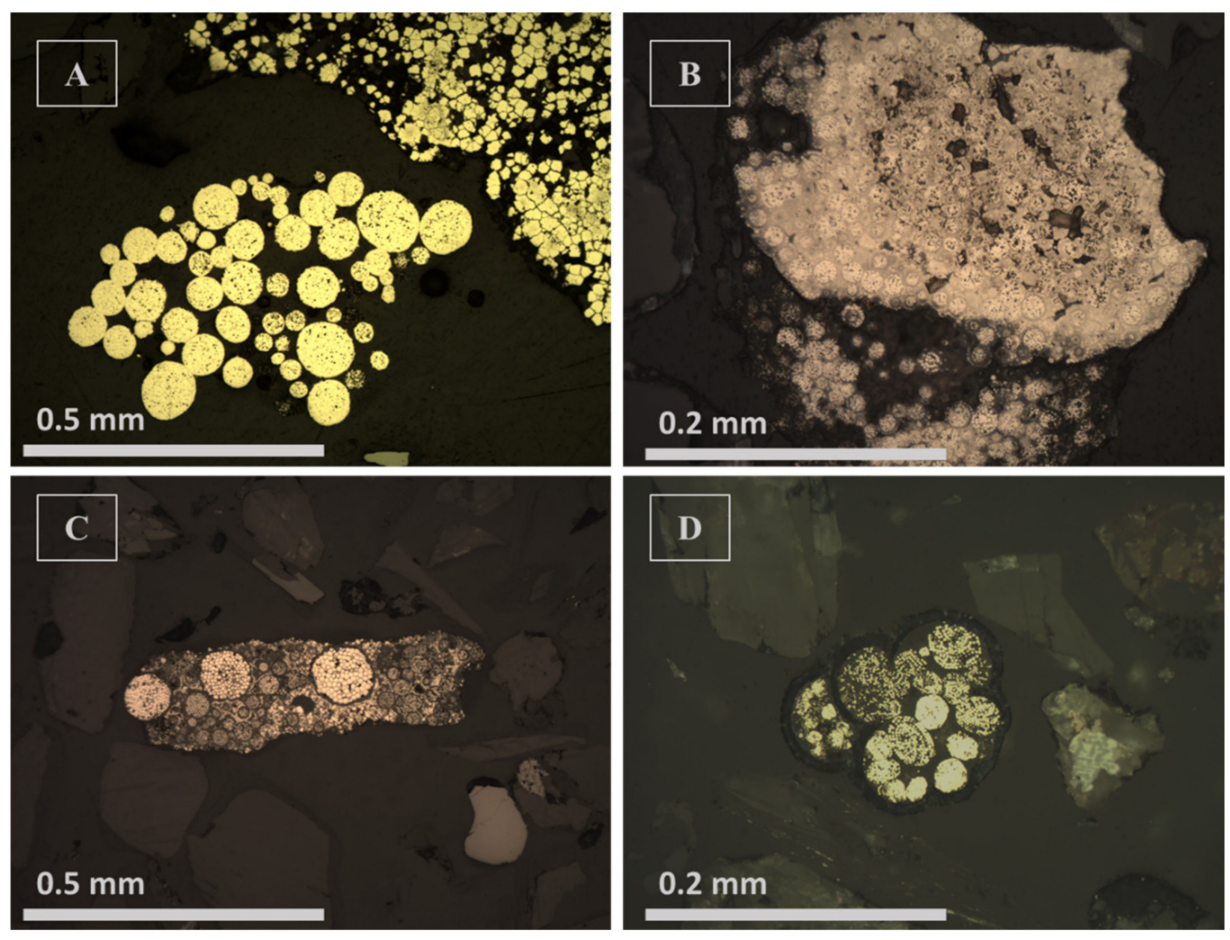

Figure 5. Framboidal pyrites. (A): Framboids developed in cavities, sample 1. (B): Weak nucleation of framboids in sample 5. (C): Framboidal pyrite in algae, sample 8. (D): Framboids inside globigerina, sample 9 . 
Three reflective metallic grains were found in the southern part of the area, and the two largest, from the external platform samples, were analyzed by SEM-EDS. In samples 10 and 11, from 317 and $2952 \mathrm{~m}$ depth respectively, two metallic-red grains presented angular forms with irregular edges (Figure 6A,B). The largest crystal of sample 10 had a dimension of $0.86 \mathrm{~mm}$ by $0.43 \mathrm{~mm}$. Several SEM point analyses in this grain showed high oxygen, copper, and carbon contents (Figure 7A). Oxygen varied from 43.4 to $52.6 \mathrm{wt.} \%$. $\mathrm{Cu}$ contents had noticeable variations between each analyzed point, showing the highest value of $44 \mathrm{wt} . \%$ in one extreme of the grain and decreasing to $29.6 \mathrm{wt} . \%$ to the another extreme. The elements $\mathrm{C}$ and $\mathrm{S}$ were identified in all points, with averages of 13.7 and $1.2 \mathrm{wt} . \%$, respectively. Additionally, Zn (3.23 wt.\%), Sn (<3.94 wt.\%), and Al (0.96 wt.\%) were detected in some point analyses.
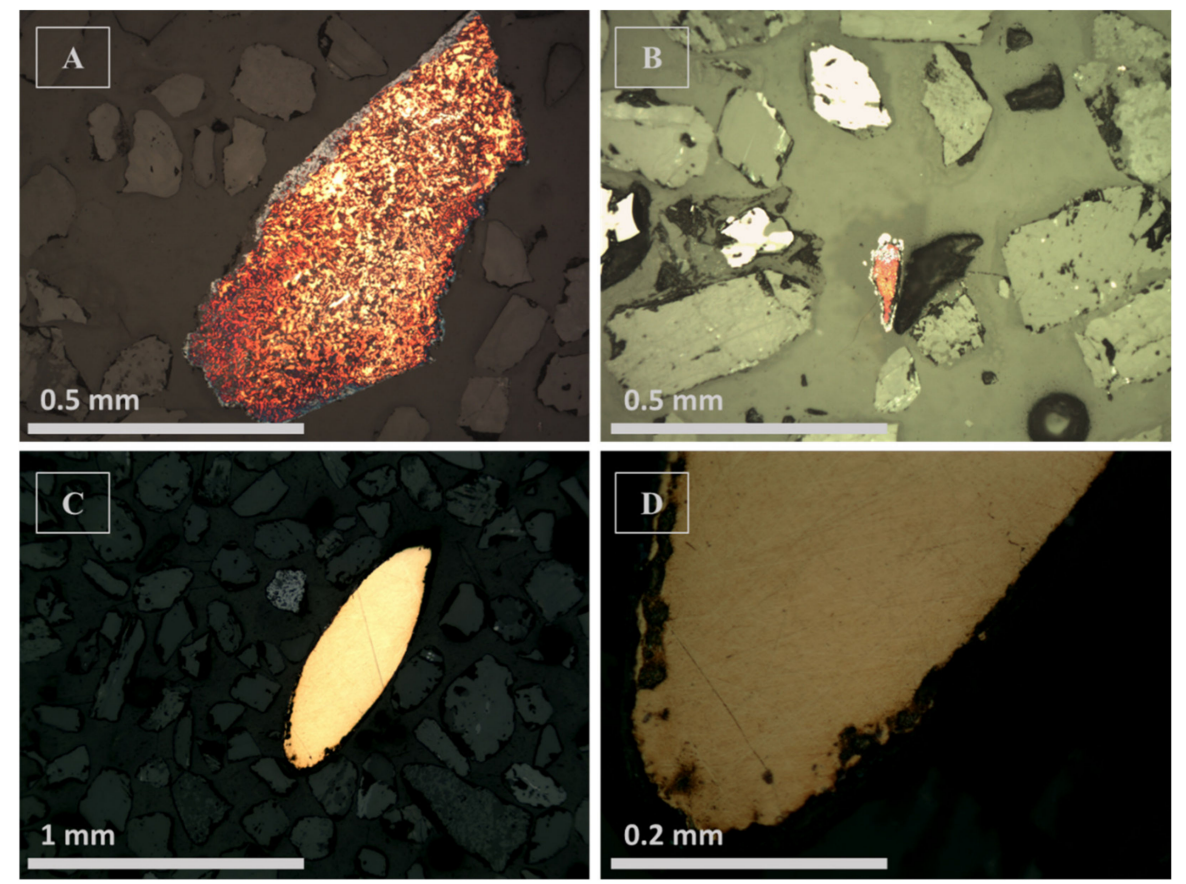

Figure 6. Copper-rich grains. (A): Sample 10. (B): Sample 11. (C,D): Sample 5.

\begin{tabular}{|c|c|c|c|c|c|c|c|c|}
\hline A Analyzed point & & $\begin{array}{c}\mathrm{C} \\
\text { (wt.\%) }\end{array}$ & $\underset{\text { (wt.\%) }}{\mathrm{Cu}}$ & $\underset{\text { (wt.\%) }}{\mathbf{O}}$ & $\underset{\text { (wt.\%) }}{\text { Sn }}$ & $\begin{array}{c}\mathbf{S} \\
\text { (wt.\%) }\end{array}$ & $\underset{\text { (wt.\%) }}{\mathrm{Zn}}$ & $\begin{array}{c}\mathrm{Al} \\
\text { (wt.\%) }\end{array}$ \\
\hline & 1 & 15.97 & 29.62 & 52.64 & 0 & 1.77 & 0 & 0 \\
\hline & 2 & 14.49 & 32.04 & 49.13 & 0 & 1.11 & 3.23 & 0 \\
\hline & 3 & 12.79 & 34.95 & 46.33 & 3.94 & 1.02 & 0 & 0.96 \\
\hline & 4 & 11.59 & 43.99 & 43.43 & 0 & 0.98 & 0 & 0 \\
\hline B & & $\underset{\text { (wt.\%) }}{\mathrm{C}}$ & $\underset{\text { (wt.\%) }}{\mathrm{Cu}}$ & $\underset{\text { (wt.\% }}{\mathbf{O}}$ & & $\begin{array}{l}\text { Mo } \\
\text { (wt.\%) }\end{array}$ & $\underset{\text { (wt.\%) }}{\mathbf{S}}$ & $\underset{\text { (wt.\%) }}{\mathbf{Z n}}$ \\
\hline & 1 & 7.66 & 53.99 & 35.4 & & 2.89 & 0 & 0 \\
\hline & 2 & 7.37 & 58.31 & 34.3 & & 0 & 0 & 0 \\
\hline & 3 & 6.98 & 57.69 & 34.4 & & 0 & 0.89 & 0 \\
\hline $0.5 \mathrm{~mm}$ & 4 & 9.43 & 38.2 & 38.2 & & 0 & 0 & 13.61 \\
\hline
\end{tabular}

Figure 7. SEM-EDS results. (A): Grain from sample 10. (B): Grain of sample 5. 
In sample 5, collected from the outer continental shelf (at $226 \mathrm{~m}$ depth) north of Ipún Island, an oval and highly reflective grain was observed, with a major axis length of $0.8 \mathrm{~mm}$ and a minor axis length of $0.3 \mathrm{~mm}$ (Figure 6C,D). The SEM-EDS point analyses revealed $\mathrm{Cu}$ contents of up to $58.3 \mathrm{wt} . \%$ with a decreasing concentration towards the edges (Figure 7B). Likewise, the oxygen average content was $35.6 \mathrm{wt} . \%$; O increases when $\mathrm{Cu}$ diminishes. Carbon occurred in small quantities $(\leq 9.4 \mathrm{wt} . \%)$; however, it was present at all analyzed points with marginal changes. Other elements detected were Mo (2.89 wt.\%), S (0.89 wt.\%), and $\mathrm{Zn}(13.61$ wt.\%).

\subsubsection{Fractions Smaller Than $75 \mu \mathrm{m}$}

The mineral compositions of the fractions for all samples were analyzed by XRD. The mineral phases were identified through two different procedures, applying qualitative and quantitative methods (DIFFRAC.EVA $\odot$ and Match! $3 \odot$ ), and the results were very similar, including for the phases at low concentrations ( $<5 \%$ or detected). A summary of whole-sediment minerals is shown in Table 4, indicating a large presence of quartz and feldspars, similar to that determined in the coarser fractions. Hornblende and actinolite were commonly detected and were particularly widespread on the continental shelf. Pyroxenes represented up to $13 \%$ of the fine fractions and were detected in large amounts in samples $2(10.6 \%)$ and $9(13 \%)$, which were both extracted from deep zones. From the mica group, muscovite and biotite were detected in all samples. Montmorillonite was the most abundant clay mineral, only absent in two samples (8 and 13), while the occurrence of chlorite was restricted to samples 3,8 and 16 . Other widely identified minerals were cordierite $\left((\mathrm{Mg}, \mathrm{Fe})_{2} \mathrm{Al}_{4} \mathrm{Si}_{5} \mathrm{O}_{18}\right)$ and birnessite $\left((\mathrm{Na}, \mathrm{Ca})_{0.5} \mathrm{Mn}_{2} \mathrm{O}_{4} \cdot 1.5 \mathrm{H}_{2} \mathrm{O}\right)$ in fifteen and fourteen samples, respectively. While the cordierite was mostly abundant in the external continental shelf, the birnessite was linked to submarine canyons. Furthermore, apatite, zircon, and rutile were present in some samples.

Table 4. Summary of XRD results in percentage of whole sediment fine fractions $(<75 \mu \mathrm{m})$. Mineral phases were identified using Match! 3 @ software, and values $<5 \%$ were labeled as D: detected. Dashes (-) indicate elements not detected. The qualitative results obtained by the DIFFRAC.EVA (c) software were very similar.

\begin{tabular}{|c|c|c|c|c|c|c|c|c|c|c|c|c|c|c|c|c|}
\hline Sample & 1 & 2 & 3 & 4 & 5 & 6 & 7 & 8 & 9 & 10 & 11 & 12 & 13 & 14 & 15 & 16 \\
\hline Quartz & 16.3 & 16.2 & 34.6 & 27.5 & 28.5 & 15.8 & 23.1 & 17.4 & 21.2 & 40.5 & 24.6 & 27.1 & 20.1 & 15.4 & 16.8 & 10.0 \\
\hline Albite & 16.5 & 21.3 & 30.5 & 24.6 & 22.7 & 25.6 & 1.2 & 27.7 & 8.8 & 18.2 & 22.7 & 35.1 & 23.7 & 24.7 & 23.9 & 15.7 \\
\hline Andesine & 20.4 & 11.1 & 15.8 & 9.9 & 13.6 & 12.4 & 21.7 & 7.4 & 21.5 & 11.0 & 11.7 & 14.0 & 12.7 & 17.7 & 17.9 & 10.2 \\
\hline Anorthite & 6.9 & 15.9 & $\mathrm{D}$ & 18.9 & $\mathrm{D}$ & 5.0 & 18.7 & 13.8 & 6.4 & 6.4 & $\mathrm{D}$ & 5.5 & 12.8 & $\mathrm{D}$ & 13.5 & 13.6 \\
\hline K-feldspar & 5.1 & 6.0 & $\mathrm{D}$ & $\mathrm{D}$ & 8.3 & 8.9 & 6.0 & 9.5 & 5.2 & 9.8 & $\mathrm{D}$ & $\mathrm{D}$ & 10.0 & 6.4 & 7.1 & 12.3 \\
\hline Muscovite & $\mathrm{D}$ & $\mathrm{D}$ & $\mathrm{D}$ & $\mathrm{D}$ & $\mathrm{D}$ & $\mathrm{D}$ & $\mathrm{D}$ & 6.1 & D & $\mathrm{D}$ & $\mathrm{D}$ & $\mathrm{D}$ & D & D & $\mathrm{D}$ & $\mathrm{D}$ \\
\hline Biotite & D & $\mathrm{D}$ & $\mathrm{D}$ & $\mathrm{D}$ & $\mathrm{D}$ & $\mathrm{D}$ & $\mathrm{D}$ & D & $\mathrm{D}$ & $\mathrm{D}$ & $\mathrm{D}$ & $\mathrm{D}$ & $\mathrm{D}$ & $\mathrm{D}$ & $\mathrm{D}$ & $\mathrm{D}$ \\
\hline Chlorite & - & - & $\mathrm{D}$ & - & - & - & - & $\mathrm{D}$ & - & - & - & - & - & - & - & $\mathrm{D}$ \\
\hline Montmorill. & $\mathrm{D}$ & $\mathrm{D}$ & $\mathrm{D}$ & $\mathrm{D}$ & $\mathrm{D}$ & $\mathrm{D}$ & $\mathrm{D}$ & - & D & $\mathrm{D}$ & $\mathrm{D}$ & $\mathrm{D}$ & - & $\mathrm{D}$ & $\mathrm{D}$ & $\mathrm{D}$ \\
\hline Hornblende & D & $\mathrm{D}$ & $\mathrm{D}$ & $\mathrm{D}$ & 7.5 & 9.3 & $\mathrm{D}$ & $\mathrm{D}$ & 5.7 & - & D & 6.8 & $\mathrm{D}$ & $\mathrm{D}$ & D & 8.1 \\
\hline Actinolite & $\mathrm{D}$ & $\mathrm{D}$ & $\mathrm{D}$ & $\mathrm{D}$ & $\mathrm{D}$ & $\mathrm{D}$ & $\mathrm{D}$ & $\mathrm{D}$ & $\mathrm{D}$ & $\mathrm{D}$ & $\mathrm{D}$ & D & $\mathrm{D}$ & $\mathrm{D}$ & D & $\mathrm{D}$ \\
\hline Pyroxene & 6.9 & 10.6 & $\mathrm{D}$ & $\mathrm{D}$ & $\mathrm{D}$ & $\mathrm{D}$ & 7.5 & $\mathrm{D}$ & 13.0 & 7.3 & 6.8 & $\mathrm{D}$ & 6.1 & 10.4 & $\mathrm{D}$ & 8.7 \\
\hline Epidote & 7.0 & $\mathrm{D}$ & - & - & - & 6.5 & 5.3 & $\mathrm{D}$ & - & - & 6.4 & - & D & 7.4 & $\mathrm{D}$ & 10.7 \\
\hline Cordierite & $\mathrm{D}$ & $\mathrm{D}$ & - & $\mathrm{D}$ & $\mathrm{D}$ & $\mathrm{D}$ & $\mathrm{D}$ & $\mathrm{D}$ & D & $\mathrm{D}$ & $\mathrm{D}$ & D & $\mathrm{D}$ & $\mathrm{D}$ & $\mathrm{D}$ & $\mathrm{D}$ \\
\hline Titanite & 9.8 & $\mathrm{D}$ & $\mathrm{D}$ & 6.7 & 5.1 & 5.3 & 3.8 & D & D & D & D & D & $\mathrm{D}$ & D & D & $\mathrm{D}$ \\
\hline Apatite & $\mathrm{D}$ & $\mathrm{D}$ & - & - & $\mathrm{D}$ & $\mathrm{D}$ & $\mathrm{D}$ & D & - & - & D & - & D & D & D & $\mathrm{D}$ \\
\hline Zircon & D & $\mathrm{D}$ & - & - & - & D & $\mathrm{D}$ & D & D & - & - & - & - & $\mathrm{D}$ & $\mathrm{D}$ & $\mathrm{D}$ \\
\hline Rutile & - & D & - & $\mathrm{D}$ & - & D & - & - & - & - & - & - & - & - & - & - \\
\hline Birnessite & D & $\mathrm{D}$ & $\mathrm{D}$ & $\mathrm{D}$ & $\mathrm{D}$ & D & $\mathrm{D}$ & $\mathrm{D}$ & $\mathrm{D}$ & $\mathrm{D}$ & $\mathrm{D}$ & $\mathrm{D}$ & - & $\mathrm{D}$ & - & $\mathrm{D}$ \\
\hline
\end{tabular}

Eight samples subjected to separation of heavy minerals $\left(>2.8 \mathrm{~g} / \mathrm{cm}^{3}\right)$ yielded sufficient material smaller than $75 \mu \mathrm{m}$ for XRD analysis (Table 5). These samples showed a dominance of pyroxenes and amphiboles, among which hornblende was the most abundant, whereas actinolite was higher only in sample 9 at 27.3\%. Epidote was present in all these concentrates at $>5 \%$, in contrast to the whole sediments wherein this mineral was detected in some samples at $<10 \%$. Similarly, carbonates, oxides, and sulfides were identified. Dolomite $\left(\mathrm{CaMg}\left(\mathrm{CO}_{3}\right)\left(\mathrm{CO}_{3}\right)\right)$, rhodochrosite $\left(\mathrm{MnCO}_{3}\right)$, and siderite $\left(\mathrm{FeCO}_{3}\right)$ 
were widely distributed. Sphalerite (ZnS) was registered in all samples in amounts up to $6.4 \%$. Likewise, tennantite $\left(\mathrm{Cu}_{12} \mathrm{As}_{4} \mathrm{~S}_{13}\right)$ and tellurobismuthite $\left(\mathrm{Bi}_{2} \mathrm{Te}_{3}\right)$ were present in all samples. As in the whole sediment, birnessite appeared in many samples. In six samples extracted from the northern side of the Chonos Archipelago, tenorite $(\mathrm{CuO})$ was detected. Pyrite $\left(\mathrm{FeS}_{2}\right)$ was sparsely detected in samples 9, 11, and 12; two of these samples came from the mouth zones of the Simpson and Darwin canyons. Goethite $(\alpha-\mathrm{FeOOH})$ was present in samples 8,10 , and 12; the latter two were collected from the continental shelf. Ilmenite $\left(\mathrm{FeTiO}_{3}\right)$ was slightly detected in samples 9, 10, 11, 12, and 13. Chalcopyrite and hematite $\left(\mathrm{Fe}_{2} \mathrm{O}_{3}\right)$ were restricted to samples 11 and 12, both extracted from the southern part of the study zone.

Table 5. Summary of XRD results in percentage of the heavy mineral fine fractions $(<75 \mu \mathrm{m})$. Mineral phases were identified using Match! 3 @ software, and values $<5 \%$ were labeled as D: detected. Dashes (-) indicate elements not detected. The qualitative results of obtained by the DIFFRAC.EVA $\odot$ software were very similar.

\begin{tabular}{|c|c|c|c|c|c|c|c|c|}
\hline Sample & 3 & 5 & 8 & 9 & 10 & 11 & 12 & 13 \\
\hline Pyroxene & 67.3 & 18.2 & 20.1 & 36.2 & 25.9 & 28.5 & 33.3 & 26.8 \\
\hline Hornblende & $\mathrm{D}$ & 37.7 & 33.9 & 6.8 & 21.2 & 38.4 & 12.3 & 28.8 \\
\hline Actinolite & 8.0 & 6.4 & 12.5 & 27.3 & 6.4 & 5.4 & 8.9 & $\mathrm{D}$ \\
\hline Biotite & $\mathrm{D}$ & $\mathrm{D}$ & $\mathrm{D}$ & - & $\mathrm{D}$ & - & - & - \\
\hline Olivine & 一 & - & - & $\mathrm{D}$ & $\mathrm{D}$ & $\mathrm{D}$ & 5.6 & - \\
\hline Epidote & 5.1 & 20.3 & 16.3 & 5.6 & 21.4 & 9.2 & 18 & 15.6 \\
\hline Garnet & $\mathrm{D}$ & $\mathrm{D}$ & 一 & $\mathrm{D}$ & $\mathrm{D}$ & $\mathrm{D}$ & $\mathrm{D}$ & - \\
\hline Titanite & $\mathrm{D}$ & 6.3 & $\mathrm{D}$ & $\mathrm{D}$ & 9.8 & $\mathrm{D}$ & $\mathrm{D}$ & 7.1 \\
\hline Apatite & $\mathrm{D}$ & 7.9 & 一 & 5.1 & $\mathrm{D}$ & $\mathrm{D}$ & $\mathrm{D}$ & - \\
\hline Zircon & $\mathrm{D}$ & $\mathrm{D}$ & $\mathrm{D}$ & $\mathrm{D}$ & $\mathrm{D}$ & $\mathrm{D}$ & $\mathrm{D}$ & $\mathrm{D}$ \\
\hline Rutile & 一 & $\mathrm{D}$ & 一 & $\mathrm{D}$ & $\mathrm{D}$ & $\mathrm{D}$ & $\mathrm{D}$ & $\mathrm{D}$ \\
\hline Birnessite & $\mathrm{D}$ & D & $\mathrm{D}$ & $\mathrm{D}$ & $\mathrm{D}$ & $\mathrm{D}$ & $\mathrm{D}$ & - \\
\hline Tellurobismuthite & $\mathrm{D}$ & $\mathrm{D}$ & $\mathrm{D}$ & $\mathrm{D}$ & $\mathrm{D}$ & $\mathrm{D}$ & $\mathrm{D}$ & $\mathrm{D}$ \\
\hline Dolomite & $\mathrm{D}$ & $\mathrm{D}$ & $\mathrm{D}$ & $\mathrm{D}$ & $\mathrm{D}$ & $\mathrm{D}$ & $\mathrm{D}$ & $\mathrm{D}$ \\
\hline Siderite & $\mathrm{D}$ & $\mathrm{D}$ & $\mathrm{D}$ & $\mathrm{D}$ & $\mathrm{D}$ & $\mathrm{D}$ & $\mathrm{D}$ & 5.4 \\
\hline Rhodochrosite & $\mathrm{D}$ & $\mathrm{D}$ & $\mathrm{D}$ & $\mathrm{D}$ & $\mathrm{D}$ & $\mathrm{D}$ & $\mathrm{D}$ & $\mathrm{D}$ \\
\hline Hematite & 一 & - & 一 & 一 & 一 & $\mathrm{D}$ & $\mathrm{D}$ & - \\
\hline Goethite & 一 & - & $\mathrm{D}$ & 一 & $\mathrm{D}$ & 一 & $\mathrm{D}$ & - \\
\hline Ilmenite & - & - & 一 & $\mathrm{D}$ & $\mathrm{D}$ & $\mathrm{D}$ & $\mathrm{D}$ & $\mathrm{D}$ \\
\hline Pyrite & 一 & - & 一 & $\mathrm{D}$ & - & $\mathrm{D}$ & $\mathrm{D}$ & - \\
\hline Chalcopyrite & $\mathrm{D}$ & 一 & 一 & 一 & - & $\mathrm{D}$ & $\mathrm{D}$ & - \\
\hline Tennantite & $\mathrm{D}$ & $\mathrm{D}$ & $\mathrm{D}$ & $\mathrm{D}$ & $\mathrm{D}$ & $\mathrm{D}$ & $\mathrm{D}$ & $\mathrm{D}$ \\
\hline Sphalerite & $\mathrm{D}$ & $\mathrm{D}$ & $\mathrm{D}$ & 6.4 & $\mathrm{D}$ & $\mathrm{D}$ & $\mathrm{D}$ & $\mathrm{D}$ \\
\hline Tenorite & - & $\mathrm{D}$ & $\mathrm{D}$ & $\mathrm{D}$ & $\mathrm{D}$ & $\mathrm{D}$ & $\mathrm{D}$ & - \\
\hline Enargite & 一 & - & 一 & - & 一 & 一 & $\mathrm{D}$ & - \\
\hline
\end{tabular}

\subsection{Geochemistry}

Geochemical whole-sediment data were obtained through ICP-ES and ICP-MS analysis for 41 elements from 16 samples, and through ICP-ES analysis for Au and Pt from 12 samples. Duplicate samples and repetition analyses indicated consistent chemical results (Table S1). Concentrations of eight elements ( $\mathrm{Ag}, \mathrm{Be}, \mathrm{Bi}, \mathrm{Cd}, \mathrm{Sb}, \mathrm{Se}, \mathrm{Ta}$, and $\mathrm{Pt}$ ) were below the detection limit in more than $50 \%$ of samples (Table S1) and these elements were therefore excluded from the analysis and statistical study. The average content of loss on ignition (LOI) was $10.8 \mathrm{wt} . \%$, a relatively high value in comparison with common wholerock analysis (Table S1). This was consistent with the preliminarily observed contents of organic matter, carbonates, and salts.

\subsubsection{Univariate Analysis}

The threshold values for each element were compared to average compositions of continental crust [57] and pelagic sediments [7] (Table 6). Positive anomalies of As, Au, Ca, $\mathrm{Li}, \mathrm{Na}, \mathrm{S}, \mathrm{V}$, and $\mathrm{Zn}$ were obtained in relation to the average continental crust [57], and 
positive anomalies of $\mathrm{Ca}, \mathrm{Na}, \mathrm{S}, \mathrm{Sr}, \mathrm{Ti}$, and $\mathrm{V}$ in relation to the average pelagic sediments [7]. Some distributions of enriched elements had similar patterns (Figure 8); consequently, the maximum anomalies were concentrated in the same samples. Thus, the highest contents of $\mathrm{Ca}, \mathrm{Sr}, \mathrm{Ti}$, and $\mathrm{V}$ were found in sample 15, from the inner shelf area, as well as the lowest concentrations of $\mathrm{Na}$ and $\mathrm{S}$. Also, it is important to note that while As, $\mathrm{Li}$, and $\mathrm{Zn}$ concentrations were above the average continental crust abundance, they were depleted in relation to the average pelagic sediments. In contrast, Ti and Sr appeared above the average composition of pelagic sediments but below the average continental crust concentrations (Figure 8B).

Table 6. Univariate statistical of the studied samples and, for comparison, average composition of continental crust and pelagic sediments [7,57]. The number of analyzed samples was 16, except for Au, which had 12.

\begin{tabular}{|c|c|c|c|c|c|c|c|c|}
\hline Elements & Minimum & Maximum & $\underset{(\mathrm{m})}{\text { Mean Value }}$ & $\begin{array}{c}\text { Standard } \\
\text { Deviation }(\sigma)\end{array}$ & $\begin{array}{l}\text { Standard Deviation } \\
\text { of Mean }\left(\sigma_{m}\right)\end{array}$ & $\begin{array}{c}\text { Threshold } \\
\left(\mathrm{m}+2 \times \sigma_{m}\right)\end{array}$ & $\begin{array}{l}\text { Continental Crust } \\
\text { Abundances }\end{array}$ & $\begin{array}{c}\text { Pelagic Sediments } \\
\text { Abundances }\end{array}$ \\
\hline $\mathrm{Al}(\mathrm{wt} . \%)$ & 6.58 & 8.27 & 7.47 & 0.44 & 0.11 & 7.69 & 8.23 & 8.4 \\
\hline As (ppm) & 2.5 & 17 & 8.1 & 4.12 & 1.0 & 10.1 & 1.8 & 20 \\
\hline $\mathrm{Au}(\mathrm{ppb})$ & 3 & 7 & 4.9 & 1.22 & 0.3 & 5.5 & 4 & 2 \\
\hline $\mathrm{Ba}(\mathrm{ppm})$ & 217 & 525 & 326 & 96.55 & 24.1 & 374 & 425 & 2300 \\
\hline $\mathrm{Ca}$ (wt.\%) & 2.37 & 8.29 & 4.31 & 1.39 & 0.3 & 5.01 & 4.15 & 1 \\
\hline $\mathrm{Ce}(\mathrm{ppm})$ & 28 & 38 & 32.8 & 3.04 & 0.8 & 34.3 & 60 & 101 \\
\hline Co (ppm) & 7 & 25 & 14.4 & 3.72 & 0.9 & 16.2 & 25 & 74 \\
\hline $\mathrm{Cr}(\mathrm{ppm})$ & 34 & 91 & 57.0 & 14.61 & 3.7 & 64.3 & 100 & 90 \\
\hline $\mathrm{Cu}(\mathrm{ppm})$ & 7.6 & 51.9 & 32.4 & 13.94 & 3.5 & 39.4 & 55 & 250 \\
\hline $\mathrm{Fe}(\mathrm{wt} . \%)$ & 3.12 & 7.03 & 4.91 & 1.05 & 0.3 & 5.44 & 5.63 & 6.5 \\
\hline $\mathrm{Hf}(\mathrm{ppm})$ & 1.1 & 2.6 & 1.8 & 0.42 & 0.1 & 2.0 & 3 & 4.1 \\
\hline K (wt.\%) & 0.96 & 1.74 & 1.31 & 0.21 & 0.1 & 1.42 & 2.09 & 2.5 \\
\hline $\mathrm{La}(\mathrm{ppm})$ & 13.3 & 18.6 & 15.8 & 1.77 & 0.4 & 16.7 & 30 & 42 \\
\hline $\mathrm{Li}(\mathrm{ppm})$ & 10.7 & 32.6 & 24.2 & 6.73 & 1.7 & 27.6 & 20 & 57 \\
\hline $\mathrm{Mg}$ (wt.\%) & 0.91 & 2.58 & 1.61 & 0.35 & 0.1 & 1.79 & 2.33 & 2.1 \\
\hline $\mathrm{Mn}$ (ppm) & 507 & 1112 & 728 & 122.13 & 30.5 & 789 & 950 & 6700 \\
\hline Mo (ppm) & 0.25 & 2.4 & 1.0 & 0.58 & 0.1 & 1.3 & 1.5 & 27 \\
\hline $\mathrm{Na}($ wt.\%) & 2.55 & 3.25 & 2.91 & 0.24 & 0.1 & 3.03 & 2.36 & 2.8 \\
\hline $\mathrm{Nb}(\mathrm{ppm})$ & 3 & 5.7 & 4.7 & 0.64 & 0.2 & 5.0 & 20 & 14 \\
\hline $\mathrm{Ni}(\mathrm{ppm})$ & 12.6 & 40.1 & 27.1 & 7.64 & 1.9 & 30.9 & 75 & 230 \\
\hline $\mathrm{P}(\mathrm{wt} . \%)$ & 0.07 & 0.11 & 0.09 & 0.01 & 0.003 & 0.098 & 0.105 & 0.15 \\
\hline $\mathrm{Pb}(\mathrm{ppm})$ & 8.9 & 14.1 & 11.2 & 1.51 & 0.4 & 11.9 & 12.5 & 80 \\
\hline $\mathrm{Rb}(\mathrm{ppm})$ & 29 & 62.1 & 44.5 & 8.53 & 2.1 & 48.7 & 90 & 110 \\
\hline S (wt.\%) & 0.025 & 0.45 & 0.19 & 0.12 & 0.0 & 0.25 & 0.026 & 0.2 \\
\hline $\mathrm{Sc}(\mathrm{ppm})$ & 11 & 21 & 16.9 & 2.63 & 0.7 & 18.2 & 22 & 19 \\
\hline Sn (ppm) & 0.25 & 1.4 & 1.0 & 0.34 & 0.1 & 1.1 & 2 & 4 \\
\hline $\mathrm{Sr}(\mathrm{ppm})$ & 241 & 574 & 336 & 71.98 & 18.0 & 372 & 375 & 180 \\
\hline Th (ppm) & 3.5 & 7.3 & 5.0 & 0.95 & 0.2 & 5.5 & 9.6 & 13 \\
\hline $\mathrm{Ti}$ (wt.\%) & 0.327 & 0.539 & 0.464 & 0.05 & 0.0 & 0.491 & 0.57 & 0.46 \\
\hline $\mathrm{U}(\mathrm{ppm})$ & 0.8 & 4.1 & 1.9 & 0.89 & 0.2 & 2.3 & 2.7 & 2.6 \\
\hline $\mathrm{V}(\mathrm{ppm})$ & 77 & 168 & 134 & 20.84 & 5.2 & 144 & 135 & 120 \\
\hline $\mathrm{W}(\mathrm{ppm})$ & 0.25 & 0.8 & 0.6 & 0.17 & 0.0 & 0.7 & 1.5 & 4 \\
\hline $\mathrm{Y}(\mathrm{ppm})$ & 13.4 & 21.5 & 17.8 & 2.13 & 0.5 & 18.9 & 33 & 40 \\
\hline $\mathrm{Zn}(\mathrm{ppm})$ & 49 & 138 & 87 & 28.79 & 7.2 & 101 & 70 & 170 \\
\hline $\mathrm{Zr}(\mathrm{ppm})$ & 36.3 & 80.8 & 60.7 & 13.77 & 3.4 & 67.6 & 165 & 150 \\
\hline
\end{tabular}

The copper content of samples was not elevated. Copper-rich grains detected though optical microscope and SEM analyses are not reflected in geochemical data except in the sample 11 that slightly exceeds the continental crust average concentration.

The Au concentrations of 11 analyzed samples showed values between 4 and $7 \mathrm{ppb}$ (with small variations), which were slightly higher than average continental crust abundance $(4 \mathrm{ppb})$. Only sample 12 was depleted. All samples were above the average content of pelagic sediments ( $2 \mathrm{ppb})$.

\subsubsection{Multivariate Analysis}

A Pearson's correlation matrix was generated (Figure 9). In addition to element abundances, granulometric contents and depths were included in the matrix. On the base of Pearson's correlation values higher than 0.75, 10 elemental associations indicated 9 mineral, rock, and mineral deposit associations, in accordance with Andrew-Jones [58] (Tables 7 and 8). Associations showed a clear link to the continental lithologies (granitic, mafic, metamorphic) and ore deposits hosted on the mainland, with the presence of skarn, precious metals, epithermal and polymetallic veins, and replacement deposits. Although the copper contents were not elevated, the Pearson's correlation element associations 
indicated a link to polymetallic deposits. Mn was present in several associations and linked to oxides.
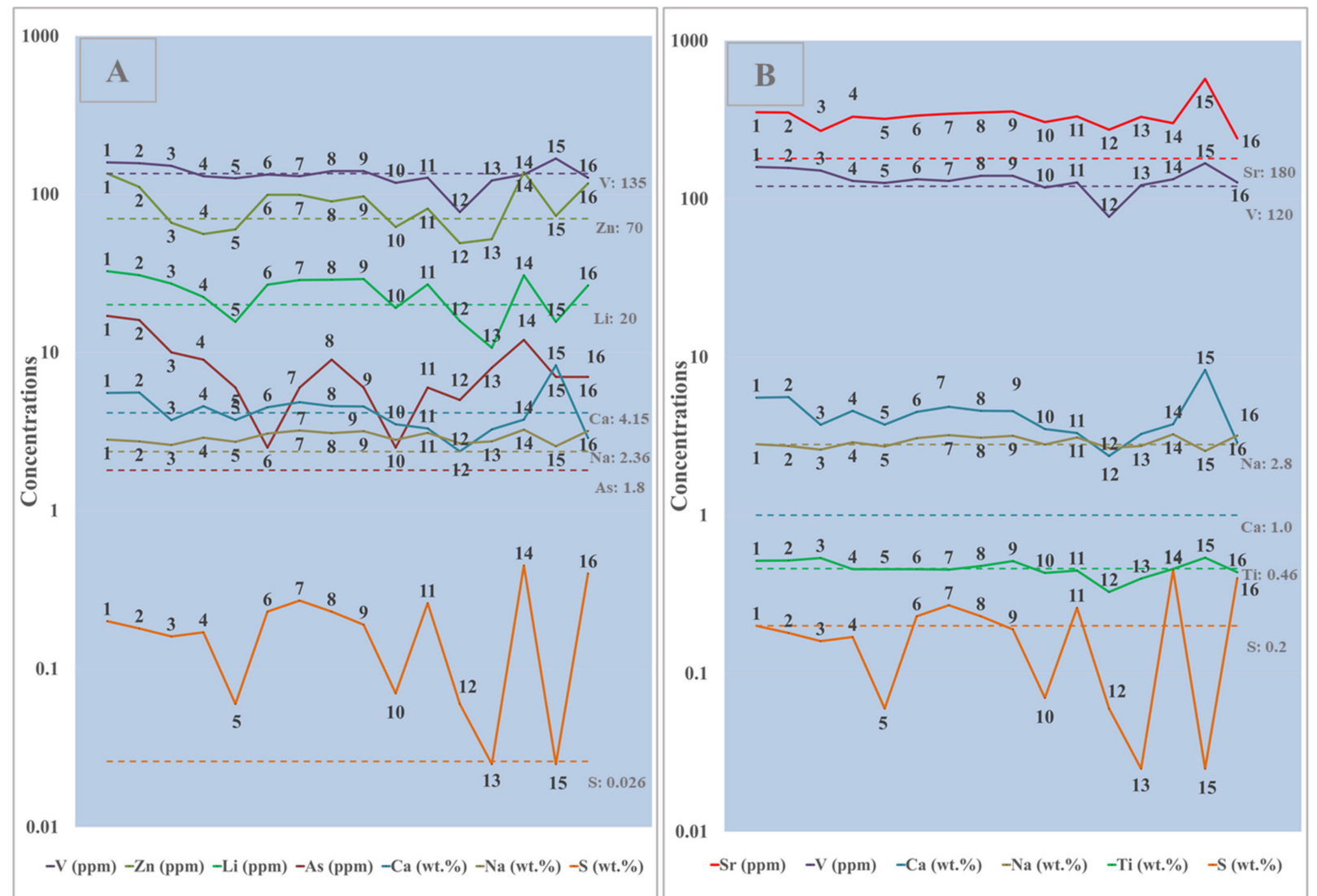

Figure 8. (A): Anomalous elements in relation to average continental crust [57]. (B): Anomalous elements in relation to average pelagic sediments [7].

Table 7. Associations with correlation factors greater than 0.75 in the Pearson's correlation matrix.

\begin{tabular}{c}
\hline Elemental Associations \\
Ca-Co-Mg-Sc-Sr-Ti-V \\
Co-Mn-Ni-Sc-Ti-Zr-Co-Mg-V \\
Cr-Hf-Sc-Ti-Y \\
Cu-Sn-Zn \\
Fe-Sc-Ti-V \\
Hf-Ni-Sc-Sn-Ti-U-V-Y-Zr \\
Li-Mo-S-Sn-U-Zn \\
Mg-Mn-Ni-Sc-Ti-Zr-V \\
Nb-Th-Y \\
Sn-Ti-U-V-Y-Zr \\
\hline
\end{tabular}

Table 8. Link between elemental associations and minerals, rocks, and mineral deposits observed in the study area.

\begin{tabular}{cc}
\hline Correlation & Ore Deposit, Mineral, and Rock \\
\hline Zn-Cu & Skarn and epithermal deposits \\
Cu-Mo & Porphyry Cu-Mo deposits \\
Ti-V-Sc & Mafic rocks \\
Mn-Ti-V & Epidote \\
Sn-Zr-Hf-U-Ti & Granitic rocks and zircon \\
Ti-Mn-Ni-V & Amphiboles and pyroxenes \\
Ti-Ca-V-Sr-Co & Biotite \\
Ti-Al-Cr-V & Magnetite \\
Mn-Co-Ni-V & Mn oxides \\
\hline
\end{tabular}




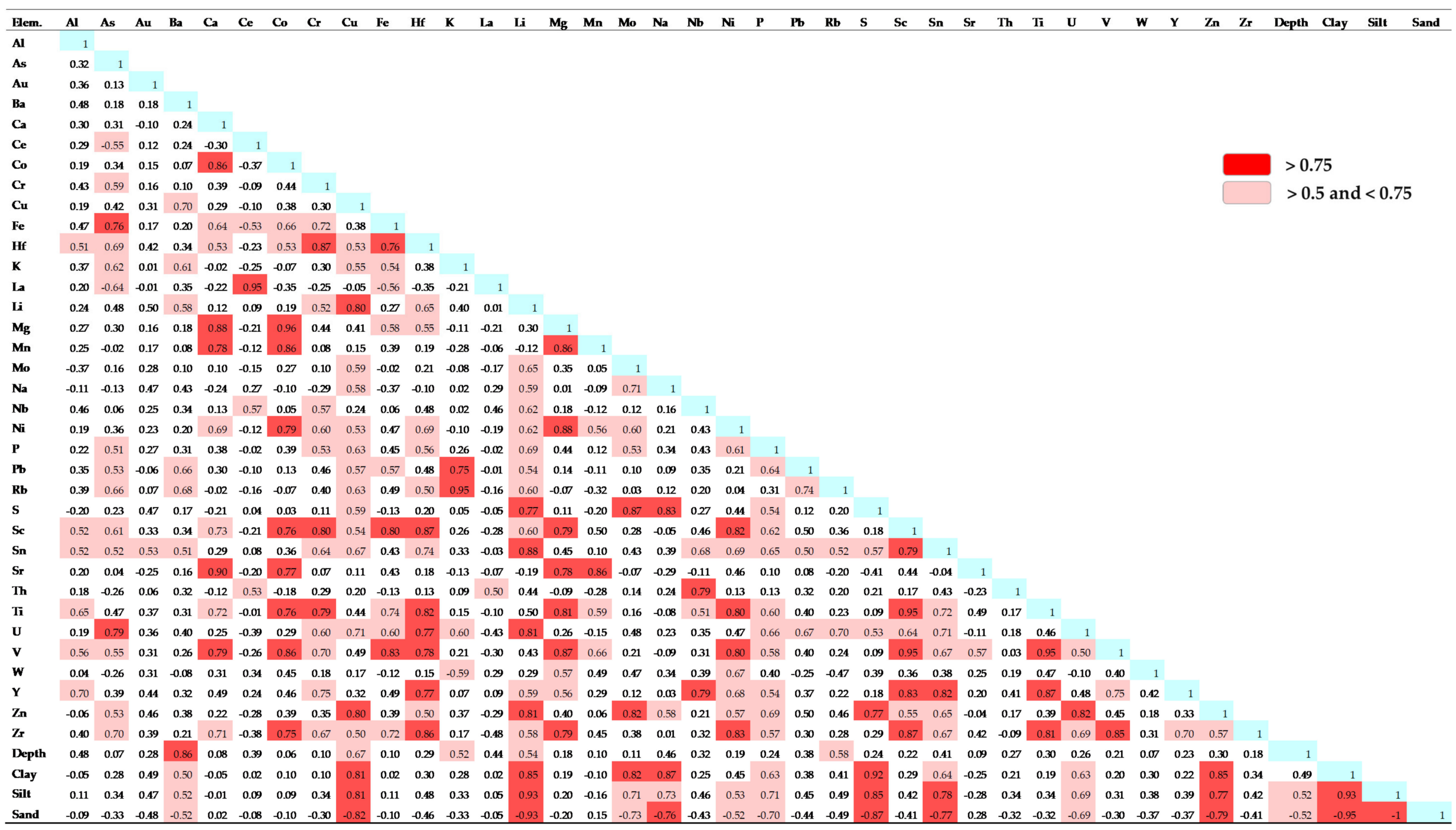

Figure 9. Pearson's correlation matrix of statistically valid elements, depth, and contents of clay, silt, and sand. 
The clay fraction had a positive Pearson's correlation coefficient for the majority of elements (Figure 9). Pearson's correlation coefficients $>0.75$ were observed for $\mathrm{Cu}, \mathrm{Li}, \mathrm{Na}$, S, U, and Zn (Figures 9 and 10). The link between the clay contents and these element concentrations was more obvious for the samples collected from submarine canyons; these had a larger proportion of clay fraction compared to the continental shelf samples (except samples 14 and 16). Sample 15, with the lowest clay content, was enriched in $\mathrm{Cu}$ and $\mathrm{Zn}$ compared to samples with similar clay contents. Similarly, samples 1 and 2 showed $\mathrm{Cu}, \mathrm{Li}$, $\mathrm{U}$, and $\mathrm{Zn}$ concentrations above the correlation line.

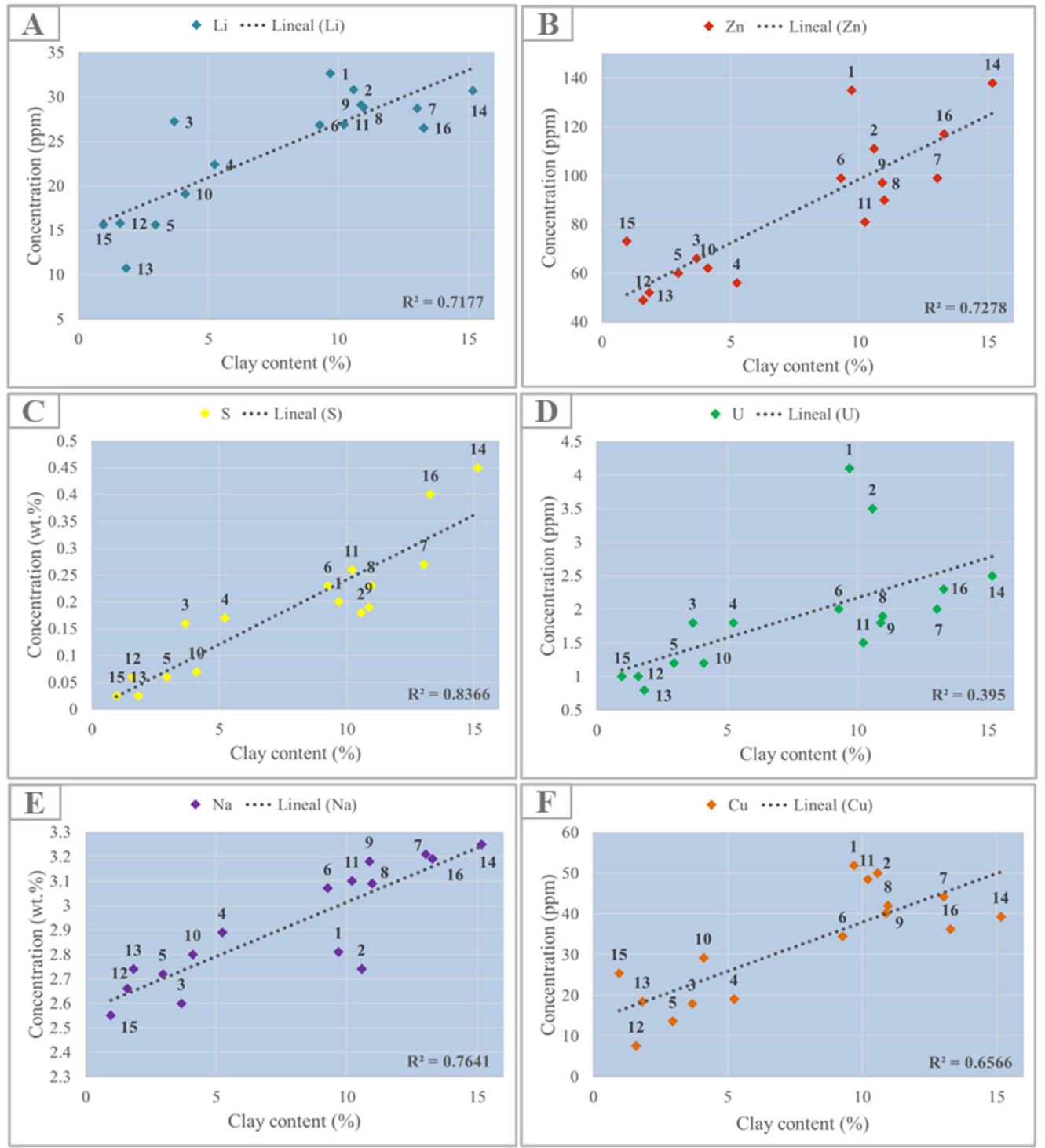

Figure 10. Elements with Pearson's correlation factors greater than 0.75 in relation to clay contents. (A): Li. (B): Zn. (C): S. (D): U. (E): Na. (F): Cu.

The correlations between depth and elemental content were generally positive, i.e. similar to the results for the clay contents. Fe and Mn contents in all samples did not have the same behavior in relation to depth; the correlation was positive, with a very low correlation coefficient (Figure 11). With aim to analyze this relation in a limited zone, we took the samples from the Simpson Canyon (from 917 to $3388 \mathrm{~m}$ depth); the concentrations of $\mathrm{Mn}, \mathrm{Fe}, \mathrm{Ba}, \mathrm{Mg}, \mathrm{K}$, and $\mathrm{Zr}$ increased with depth (Figure 12). Ba presented the highest increase at 52\%. Meanwhile, Mn, $\mathrm{Zr}, \mathrm{K}, \mathrm{Fe}$, and $\mathrm{Mg}$ showed a rise of 19, 15, 12, 11, and $9 \%$, respectively. Furthermore, the greatest concentration changes were not closely related 
to the largest depth variations; Ba increased $89 \mathrm{ppm}$ between 917 and $1070 \mathrm{~m}$ depth, and $79 \mathrm{ppm}$ between 1619 and $3388 \mathrm{~m}$ depth. Mn contents showed the highest increase (70 ppm) between 1070 and $1619 \mathrm{~m}$ depth.

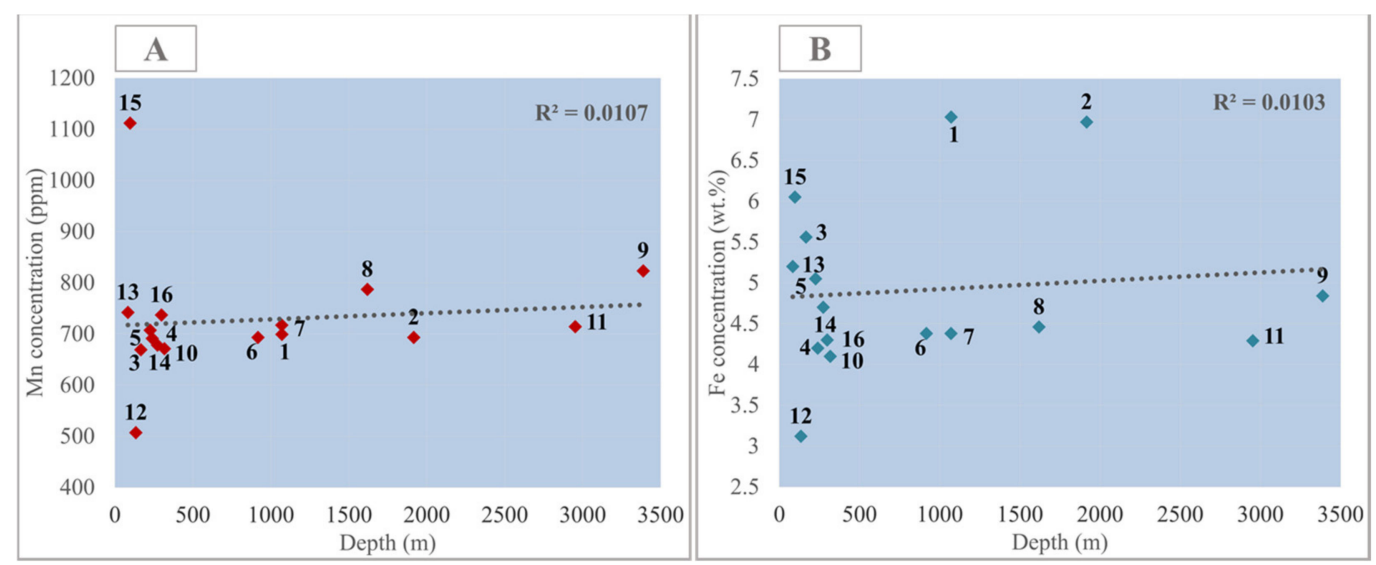

Figure 11. (A): Mn concentrations in relation to sample depth. (B): Fe concentrations in relation to sample depth.

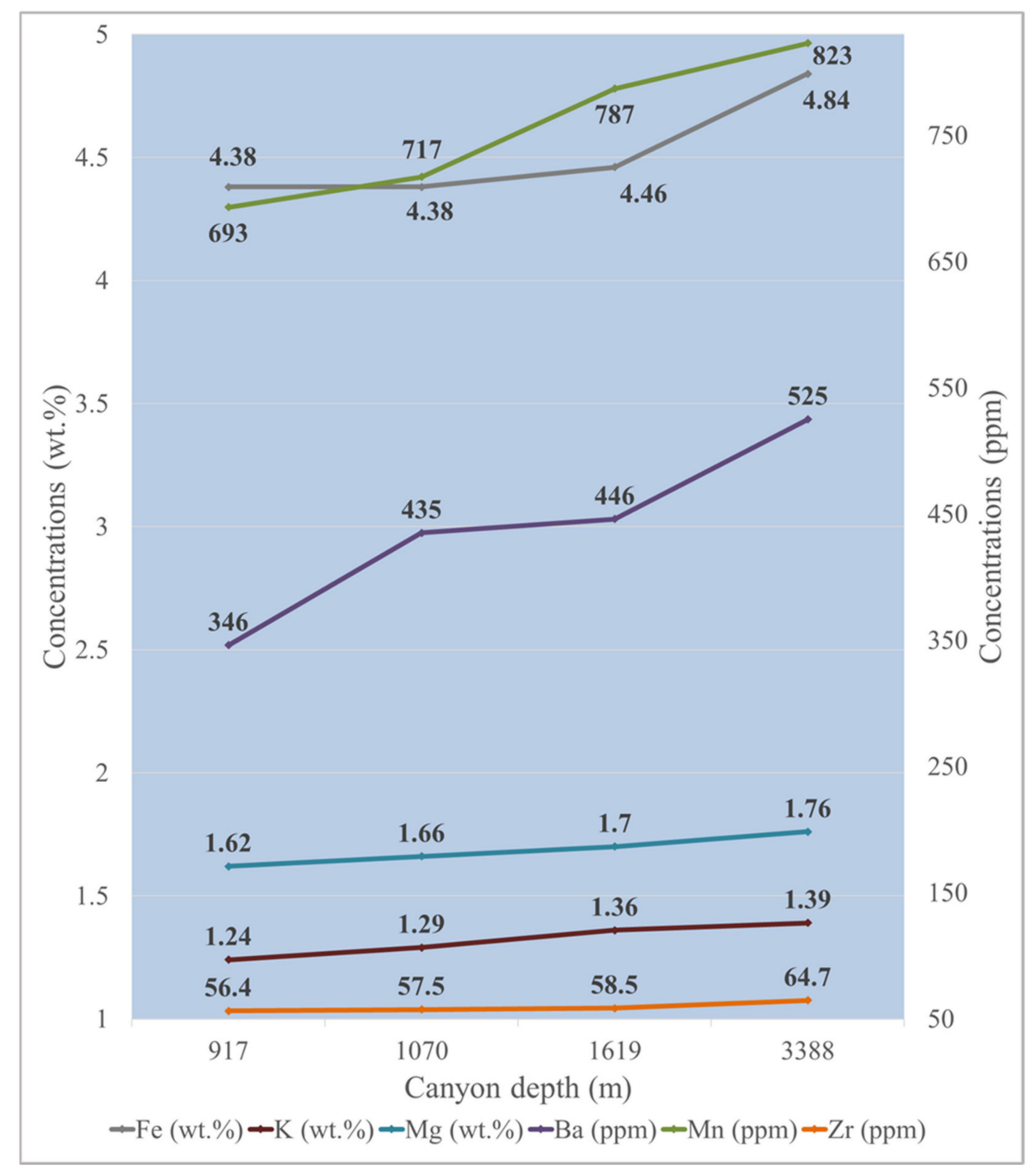

Figure 12. Elements with increasing concentrations in Simpson Canyon. 


\section{Discussion}

The XRD results revealed the widespread presence of birnessite and tellurobismuthite, although with contents less than $5 \%$. Birnessite is a Mn oxide, one of the principal phases found in ferromanganese nodules, and tellurium and bismuth have been linked to $\mathrm{Fe}-\mathrm{Mn}$ crust deposits [3]. Birnessite occurs commonly as microcrystals and is usually detected by SEM and XRD [59-63]. Although this has been described in several settings, the detailed environment of its occurrence is poorly known. The mineral is formed in nodules by diagenetic processes, but also has been associated with low-temperature hydrothermal deposits formed by percolation through sediment piles (e.g., [7,64]). Compared to todorokite, birnessite tends to predominate at relatively shallower water depth in seamounts and ridges $[63,65]$. These characteristics are consistent with location of the studied area, near the Chile Ridge, where hydrothermal activity has been identified [66] and the depth is less than $3500 \mathrm{~m}$. Although in the Chiloé-Taitao offshore area and surroundings, some occurrences of Fe-Mn nodules have been previously identified at 1483 and $3636 \mathrm{~m}$ depths [8-10], such nodules were not detected in the present study; we also could not find micronodules. The redox conditions in deeper sediments measured herein are reducing, while moderately oxidizing environments are necessary for nodule development [67,68]. Pleistocene glaciations have influenced the nodule and crust genesis in the Southwest Pacific and Peru Basin via cold bottom currents and oxygenation of abyssal area, permitting widespread deep-sea erosion to maintain nodules at the sediment surface [6].

Pyrite framboids were widely observed, mainly at depths greater than $900 \mathrm{~m}$ in submarine canyons and continental slope. This type of pyrite is very common in anoxic lacustrine and marine sediments. Furthermore, framboidal pyrite has been related to bacterial reduction of sulfate and carbonate formation, through the anaerobic oxidation of methane [69-71]. These reactions release $\mathrm{H}_{2} \mathrm{~S}$ that in presence of $\mathrm{Fe}^{2+}$ can react to form pyrite. The concentration of methane hydrates in sediments increases with burial depth [71,72]. Methane hydrates are typically observed in accretionary prisms in subduction zones where the biological productivity is high [73]. In the studied area, they have been previously detected in the sediment column, specifically in the vicinity of the Taitao triple junction [12], and have also been inferred by means of seismic reflection $[14,15]$. Hence, it is probable that methane hydrates can exit at greater depths in the studied area and within the sediment column.

The observed grains with high copper and oxygen, and less $C$ and $S$, had not been registered previously in the area. An anthropogenic origin for these grains cannot be excluded; however, the geochemical composition does not correspond to common alloys used for ships or by the fishing industry, which have Fe and other metals and do not have $\mathrm{O}$ and S. Additionally, microfragments of the grab sampler were discarded because it was made of stainless steel (Fe-Cr alloy). Two natural $\mathrm{Cu}$ sources are possible: transportation from the continent and/or in situ diagenetic marine formation. Significant $\mathrm{Cu}$ enrichment zones are hosted on the mainland, in the Divisadero Formation and Coyhaique Group, in which the average $\mathrm{Cu}$ concentration of ore bodies reaches $0.6 \%[23,74]$. This origin might correspond to that of the angular particle from sample 10, which was located $17 \mathrm{~km}$ from the coast, in oxidizing conditions. On the other hand, native $\mathrm{Cu}$ or $\mathrm{Cu}$-bearing occurrences have been reported in seafloor massive sulfides in oceanic ridges (e.g., [75-78]) and marine sediments via in situ precipitation close to these ridges [78-82]. Volcanic activity produces a hydrothermal plume and $\mathrm{Cu}$ dispersion through the seawater. This $\mathrm{Cu}$, together with hydrogenous $\mathrm{Cu}$, precipitates in the sediments of nearby areas where the conditions are favorably reducing. As the studied area is situated close to the Chile Ridge, this potential marine origin for $\mathrm{Cu}$ cannot be discarded. This origin might correspond to that of sample $5(-31 \mathrm{mV})$, collected from the external continental shelf at $140 \mathrm{~km}$ from the Chile Ridge, and that of sample 11, collected in a submarine canyon mouth at $60 \mathrm{~km}$ from the ridge.

The occurrence of siderite has been linked to submarine hydrothermal fluids and sulfate-reducing bacteria in association with anoxic to suboxic environments [83,84]. However, in this study, the highest contents of siderite were detected in sediments sampled from 
oxidizing environments and close to the coast. This suggests that the source of siderite may be associated with reduced coastal sediments.

Regarding the geochemical data, positive anomalies with respect to the continental crust matched the anomalous elements in schists from Chiloé Island, including Au, As, Co, $\mathrm{Cu}, \mathrm{Cr}, \mathrm{Ni}$, and $\mathrm{Zn}$ [85]. Furthermore, Pearson correlations coincided with petrographic observations and XRD analysis, which showed a dominant influence of the metamorphic rocks and minerals such as actinolite and epidote.

\section{Conclusions}

Sixteen samples of superficial marine sediments were collected from the continental shelf, submarine canyons, and continental slope at depths of 83 to $3388 \mathrm{~m}$. Granulometric analyses indicated that sediments were, in order of abundance, silts, sandy silts, silty sands, and sands. Textural classification showed a dominance of sandy muds, mainly distributed in submarine canyons.

Optical microscopy of coarse fractions (greater than $75 \mu \mathrm{m}$ ) showed the extensive presence of quartz and plagioclase, and lesser proportions of pyroxenes, amphiboles, epidote, and biotite, partially affected by chloritization. Zircon, white mica, and K-feldspar were observed in low quantities, and olivine was significant in sands from inner channels. Pyrite, magnetite, hematite, and ilmenite were present in low proportions but in all samples. The lithic fragments were predominantly present at shallow depths (less than $1000 \mathrm{~m}$ ) and were mainly metamorphic and volcanic. This is consistent with found mineral phases and geochemical correlations, and with lithologies present in land. Framboidal pyrites ( $<5 \%$ in heavy mineral concentrates) were detected in cavities of bioclasts and growing on other mineral surfaces. These pyrites were widely collected, mainly from depths greater than $900 \mathrm{~m}$, in submarine canyons and continental slope, and may be related to methane hydrate occurrences, which are typical in accretionary wedges and have been reported in the studied area and surroundings [71].

In fine fractions (lower than $75 \mathrm{um}$ ), the minerals detected with XRD were similar to the minerals present in the coarse fractions. In many samples, XRD analyses detected low concentrations (less than 5\%) of tenorite, sphalerite, tennantite, cordierite, birnessite, and tellurobismuthite. Birnessite has been commonly linked to polymetallic Fe-Mn nodules, and especially to relatively shallower depths and low-temperature hydrothermal environments, whereas Te and Bi are linked to Fe-Mn crusts. Pearson geochemical correlation showed associations with Mn oxides. Our samples did not contain Fe-Mn nodules, probably due to the lack of favorable redox conditions; however, nodules may have formed in the studied area or in deeper zones.

Three reflective metallic grains were rich in copper and were found in the southern part of the study area, near the Chile Ridge. One grain, from near the coast, was angular and contained $\mathrm{Cu}$ (up to $44 \mathrm{wt.} \%$ ), O (43-53 wt.\%), and C (13.7 wt.\% on average). The sample location of this particle, oxidizing conditions, and poor rounding of the grain suggested a proximal origin from a mainland zone. The other grain, from the outer continental shelf, was highly rounded and contained up to $58.3 \mathrm{wt} \% \mathrm{Cu}$ and $35.6 \mathrm{wt}$.\% $\mathrm{O}$ on average; $\mathrm{Zn}$, $\mathrm{C}$, Mo, and $\mathrm{S}$ were present in minor proportions. Its origin might be in situ diagenetic precipitation related to the enrichment of hydrogenous $\mathrm{Cu}$ by hydrothermal activity at the Chile Ridge.

Positive anomalies of $\mathrm{As}, \mathrm{Au}, \mathrm{Ca}, \mathrm{Li}, \mathrm{Na}, \mathrm{S}, \mathrm{V}$, and $\mathrm{Zn}$ exist respective to the average continental crust, and of $\mathrm{Ca}, \mathrm{Na}, \mathrm{S}, \mathrm{Sr}, \mathrm{Ti}$, and $\mathrm{V}$ respective to the average pelagic sediments. The $\mathrm{Cu}$ content of samples was not elevated, but $\mathrm{Cu}$ phases were locally detected by XRD and Pearson's correlation element associations indicating a link to polymetallic deposits, which are present on land.

The elemental concentrations in samples tended to increase with clay content, especially for $\mathrm{Cu}, \mathrm{Li}, \mathrm{Na}, \mathrm{S}, \mathrm{U}$, and $\mathrm{Zn}$. No relevant $\mathrm{Au}$ anomalies were detected, but the shallow parts of submarine canyons were not sampled and the extension of littoral $\mathrm{Au}$ placers toward the canyons cannot be discarded. 
Supplementary Materials: The following are available online at https:/ / www.mdpi.com/article/10 $.3390 / \min 11080903 /$ s1, Table S1: Geochemical results.

Author Contributions: Conceptualization, M.G.; methodology, M.P., B.T. and K.D.; formal analysis, M.P. and M.G.; investigation, M.P., M.G., B.T. and K.D.; supervision, M.G.; writing-original draft, M.P.; writing-review \& editing, M.G., B.T. and K.D.; funding acquisition and project administration, M.G. All authors have read and agreed to the published version of the manuscript.

Funding: This work was funded by the Comité Oceanográfico Nacional de Chile (project CIMAR 24F 18-04), and the Advanced Mining Technology Center (CONICYT/PIA Project AFB180004) and Department of Geology, University of Chile.

Data Availability Statement: The results were supported by our own data.

Acknowledgments: We thank our colleagues R. Fernández, C. Rodrigo, and D. Moncada for fruitful discussions and the crew of the Cabo de Hornos vessel for their fundamental support on board. R. Valles, Z. Salinas, J. Vargas, and A. Ibáñez, from the laboratories of the University of Chile, collaborated on the preparation and analysis of samples. Finally, we thank our three anonymous reviewers for important improvements to this paper.

Conflicts of Interest: The authors declare no conflict of interest.

\section{References}

1. Cronan, D.S. Handbook of Marine Mineral Deposits; CRC Press: Boca Raton, FL, USA, 2000.

2. Rona, P.A. The Changing Vision of Marine Minerals. Ore Geol. Rev. 2008, 33, 618-666. [CrossRef]

3. Hein, J.R.; Mizell, K.; Koschinsky, A.; Conrad, T.A. Deep-Ocean Mineral Deposits as a Source of Critical Metals for High- and Green-Technology Applications: Comparison with Land-Based Resources. Ore Geol. Rev. 2013, 51, 1-14. [CrossRef]

4. Lusty, P.A.J.; Murton, B.J. Deep-Ocean Mineral Deposits: Metal Resources and Windows into Earth Processes. Elements 2018, 14, 301-306. [CrossRef]

5. Kret, K.; Tsuji, T.; Chhun, C.; Takano, O. Distributions of Gas Hydrate and Free Gas Accumulations Associated with Upward Fluid Flow in the Sanriku-Oki Forearc Basin, Northeast Japan. Mar. Pet. Geol. 2020, 116, 104305. [CrossRef]

6. Glasby, G.P.; Stoffers, P.; Sioulas, A.; Thijssen, T.; Friedrich, G. Manganese Nodule Formation in the Pacific Ocean: A General Theory. Geo-Marine 1982, 2, 47-53. [CrossRef]

7. Li, Y.-H.; Schoonmaker, J.E. Chemical Composition and Mineralogy of Marine Sediments. In Treatise on Geochemistry; Elsevier Science: Oxford, UK, 2003; Volume 7, pp. 1-35.

8. García, M.; Correa, J.; Maksaev, V.; Townley, B. Potential Mineral Resources of the Chilean Offshore: An Overview. Andean Geol. 2020, 47, 1-13. [CrossRef]

9. Rosato, V.J.; Kulm, L.D.; Derks, P.S. Surface Sediments of the Nazca Plate. Pac. Sci. 1975, 29, 117-130.

10. Valenzuela, E.; Mpodozis, C.; Morales, E.; Parra, J.C.; Ugarte, G.; Tello, A.R.; Quiñones, C. Anteproyecto Para La Evaluación Del Potencial Minero Del Fondo Oceánico Del Mar de Chile; Departamento de Geología Universidad de Chile: Santiago, Chile, 1984.

11. Bangs, N.L.B.; Sawyer, D.S.; Golovchenko, X. Free Gas at the Base of the Gas Hydrate Zone in the Vicinity of the Chile Triple Junction. Geology 1993, 21, 905-908. [CrossRef]

12. Froelich, P.N.; Kvenvolden, K.A.; Torres, M.E.; Waseda, A.; Didyk, B.M.; Lorenson, T.D. Geochemical Evidence for Gas Hydrate in Sediment near the Chile Triple Junction. Proc. Ocean. Drill. Progr. Sci. Results 1995, 141, 276-286.

13. Coffin, R.; Pohlman, J.; Gardner, J.; Downer, R.; Wood, W.; Hamdan, L.; Walker, S.; Plummer, R.; Gettrust, J.; Diaz, J. Methane Hydrate Exploration on the Mid Chilean Coast: A Geochemical and Geophysical Survey. J. Pet. Sci. Eng. $2007,56,32-41$. [CrossRef]

14. Vargas-Cordero, I.; Tinivella, U.; Accaino, F.; Loreto, M.F.; Fanucci, F. Thermal State and Concentration of Gas Hydrate and Free

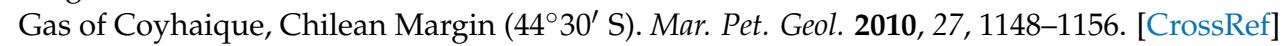

15. Vargas-Cordero, I. de la C.; Tinivella, U.; Villar-Muñoz, L.; Giustiniani, M. Gas Hydrate and Free Gas Estimation from Seismic Analysis Offshore Chiloé Island (Chile). Andean Geol. 2016, 43, 263-274. [CrossRef]

16. Pineda, V.; Contardo, X.; Alfaro, G.; Helle, S. Textural Mineralogical and Geochemical of Sediments of the Beagle Channel and Nassau Bay, XII Magallanes Region, Chile. Cienc. Tecnol. Mar. 2002, 25, 5-21.

17. Greiner, G. Características y Distribución de Los Placeres Auríferos de Chile. In Empresa Nacional de Minería; ENAMI: Santiago, Chile, 1991.

18. Portigliati, C. Los Placeres Auríferos de Chile; Servicio Nacional de Geología y Minería: Santiago, Chile, 1999; Volume 99, pp. 1-131.

19. Ordoñez, A. Oro Detrítico En La Región de Los Lagos (39-42 ${ }^{\circ}$ : Mecanismos de Transporte y Proveniencia. Serv. Nac. Geol. Min. 2000, 56, 1-40.

20. Mordojovich, C. Sedimentary Basins of Chilean Pacific Offshore, in Energy Resources of the Pacific Region. Am. Assoc. Pet. Geol. Stud. Geol. 1981, 12, 63-68. 
21. Tsandev, I.; Rabouille, C.; Slomp, C.P.; van Cappellen, P. Shelf Erosion and Submarine River Canyons: Implications for Deep-Sea Oxygenation and Ocean Productivity during Glaciation. Biogeosciences 2010, 7, 1973-1982. [CrossRef]

22. Townley, B.K.; Palacios, C.M. Ore Deposits and Metallogenesis of Mainland Patagonia, Aysen, Chile. Explor. Min. Geol. 1999, 8, 91-108.

23. Townley, B.K.; Maksaev, V.J.; Palacios, C.M.; Lahsen, A.A.; Parada, M.A.R. Base and Precious Metals Geochemistry of Rock Units of the Mainland Aysén Region, Chilean Patagonia. J. Geochem. Explor. 2000, 68, 21-46. [CrossRef]

24. Duhart, P.; Crignola, G.; Ordóñez, B.A.; Muñoz, J. Franjas Metalogénicas En Chiloé Continental ( $41^{\circ}-44^{\circ}$ S). In Proceedings of the IX Congreso Geológico Chileno, Puerto Varas, Chile, 31 July-4 August 2000; pp. 201-205.

25. Zapata, R. Estudio Batimétrico Del Margen Chileno. Master's Thesis, Universidad de Chile, Santiago, Chile, 2001.

26. Díaz-Naveas, J.; Frutos, J. Geología Marina de Chile; Comité Oceanográfico Nacional de Chile, Pontificia Universidad Católica de Valparaíso, Servicio Nacional de Geología y Minería de Chile: Santiago, Chile, 2010; pp. 60-65.

27. Bird, P. An Updated Digital Model of Plate Boundaries. Geochem. Geophys. Geosyst. 2003, 4. [CrossRef]

28. Herron, E.M.; Hayes, D.E. A Geophysical Study of the Chile Ridge. Earth Planet. Sci. Lett. 1969, 6, 77-83. [CrossRef]

29. Anma, R.; Armstrong, R.; Danhara, T.; Orihashi, Y.; Iwano, H. Zircon Sensitive High Mass-Resolution Ion Microprobe U-Pb and Fission-Track Ages for Gabbros and Sheeted Dykes of the Taitao Ophiolite, Southern Chile, and Their Tectonic Implications. Isl. Arc 2006, 15, 130-142. [CrossRef]

30. Larson, R.; Searle, R.; Kleinrock, M.; Schouten, H.; Bird, R.; Naar, D.; Rusby, R.; Hooft, E.; Lasthiotakis, H. Roller-Bearing Tectonic Evolution of the Juan Fernandez Microplate. Nature 1992, 356, 571-576. [CrossRef]

31. Tebbens, S.F.; Cande, S.C.; Kovacs, L.; Parra, J.C.; LaBrecque, J.L.; Vergara, H. The Chile Ridge: A Tectonic Framework. J. Geophys. Res. B Solid Earth 1997, 102, 12035-12059. [CrossRef]

32. Richter, A.; Ivins, E.; Lange, H.; Mendoza, L.; Schröder, L.; Hormaechea, J.L.; Casassa, G.; Marderwald, E.; Fritsche, M.; Perdomo, R.; et al. Crustal Deformation across the Southern Patagonian Icefield Observed by GNSS. Earth Planet. Sci. Lett. 2016, 452, 206-215. [CrossRef]

33. Duhart, P.; Martin, M.; Muñoz, J.; Crignola, P.; McDonough, M. Acerca de La Edad Del Protolito Del Basamento Metamórfico de La Cordillera de La Costa de La X ${ }^{a}$ Región: Edades Preliminares 207Pb/206Pb En Circones Detríticos. In Proceedings of the VIII Congreso Geológico Chileno, Antofagasta, Chile, 13-17 October 1997; pp. 1267-1270.

34. Antinao, J.L.; Duhart, P.; Clayton, J.; Elgueta, S.; McDonough, M. Área de Ancud-Maullín, Región de Los Lagos, Escala 1:100.000; Servicio Nacional de Geología y Minería Mapas Geológicos: No. 17; SERNAGEOMIN: Santiago, Chile, 2000.

35. Duhart, P.; McDonough, M.; Muñoz, J.; Martin, M.; Villeneuve, M. El Complejo Metamórfico Bahía Mansa En La Cordillera de La

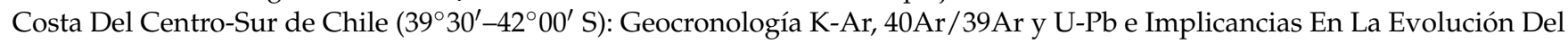
Margen Sur-Occidental de Gondwana. Rev. Geológica De Chile 2001, 28, 179-208. [CrossRef]

36. Quiroz, D.; Duhart, O.; Crignola, P. Geología Del Área Chonchi-Cucao, Región de Los Lagos, Escala 1:100.000; Carta Geológica de Chile, Serie Geología Básica, No. 86, SERNAGEOMIN: Santiago, Chile, 2004; 31 p.

37. Pankhurst, R.J.; Weaver, S.D.; Hervé, F.; Larrondo, P. Mesozoic-Cenozoic Evolution of the North Patagonian Batholith in Aysén, Southern Chile. J. Geol. Soc. 1999, 156, 673-694. [CrossRef]

38. Hervé, F.; Fanning, C.M. Late Triassic Detrital Zircons in Meta-Turbidites of the Chonos Metamorphic Complex, Southern Chile. Rev. Geológica Chile 2001, 28, 91-104. [CrossRef]

39. Heim, A. Geological Observations in the Patagonian Cordillera (Preliminary Report). Eclogae Geol. Helv. 1940, $33,25-51$.

40. Niemeyer, H. Geología Regional Del Territorio Comprendido Entre El Lago General Carrera y El Río Chacabuco, Provincia de Aysén. Bachelor's Thesis, Universidad de Chile, Santiago, Chile, 1975.

41. Haller, M.; Lapido, O. El Mesozoico de La Cordillera Patagónica Central. Rev. De La Asoc. Geológica Argent. 1980, 35, $230-247$.

42. De la Cruz, R.; Cortés, J. Geología Del Área Oriental de La Hoja Puerto Cisnes, Región de Aysén de General Carlos Ibáñez Del Campo, Escala 1.250.000; Servicio Nacional de Geología y Minería Mapas Geológicos, No. 127; SERNAGEOMIN: Santiago, Chile, 2011.

43. Hervé, F.; Pankhurst, R.J.; Fanning, C.M.; Calderón, M.; Yaxley, G.M. The South Patagonian Batholith: 150 My of Granite Magmatism on a Plate Margin. Lithos 2007, 97, 373-394. [CrossRef]

44. Valenzuela, E. Estratigrafía de La Boca Occidental Del Canal de Chacao, X Región, Chile. In Proceedings of the III Congreso Geológico Chileno, Concepción, Chile, 8-14 November 1982; pp. 343-376.

45. Hervé, F.; Greene, F.; Pankhurst, R.J. Metamorphosed Fragments of Oceanic Crust in the Upper Paleozoic Chonos Accretionary Complex, Southern Chile. J. South Amwicm Earth Sci. 1994, 7, 263-270. [CrossRef]

46. Quiroz, D.; Duhart, P. Geología Del Área Quellón-Isla San Pedro, Región de Los Lagos, Escala 1:100.000Servicio Nacional de Geología y Minería Mapas Geológicos, No. 94SERNAGEOMIN: Santiago, Chile, 2006; Volume 94, pp. 1-20.

47. Hervé, M. Estudio Geológico de La Falla Liquiñe-Reloncaví En El Área de Liquiñe: Antecedentes de Un Movimiento Transcurrente (Provincia de Valdivia). In Proceedings of the I Congreso Geológico Chileno; Santiago, Chile, 2-7 August 1976; pp. 39-56.

48. Hervé, F.; Pankhurst, R.J.; Drake, R.; Beck, M.E. Pillow Metabasalts in a Mid-Tertiary Extensional Basin Adjacent to the LiquifieOfqui Fault Zone: The Isla Magdalena Area, Aysbn, Chile. J. South Amwicm Earth Sci. 1995, 8, 33-46. [CrossRef]

49. Cembrano, J.; Hervé, F.; Lavenu, A. The Liquiñe Ofqui Fault Zone: A Long-Lived Intra-Arc Fault System in Southern Chile. Tectonophysics 1996, 259, 55-66. [CrossRef] 
50. Vargas, G.; Rebolledo, S.; Sepúlveda, S.A.; Lahsen, A.; Thiele, R.; Townley, B.; Padilla, C.; Rauld, R.; Herrera, M.J.; Lara, M. Ruptura Sísmica Submarina, Tectónica y Volcanismo Activo a Lo Largo de La Falla Liquiñe-Ofqui e Implicancias Para El Peligro Sísmico En Los Andes Patagónicos. Andean Geol. 2013, 40, 141-171. [CrossRef]

51. Palacios, C.; Lahsen, A.; Parada, M. Metallogenic Belts in the Chilean Patagonia, between $44^{\circ}$ and $48^{\circ}$ S. In Proceedings of the International Simposium on Andean Geodynamics, Saint Malo, France, 17-19 September 1996; Volume 9, pp. 691-694.

52. Brass, G.W.; Raman, C.V. Clay Mineralogy of Sediments from the Bengal Fan. Proc. Ocean Drill. Progr. Sci. Results 1990, $116,35-41$.

53. Nicolo, M.J.; Dickens, G.R. Data Report: Terrigenous Grain-Size Distributions at Sites 1263 and 1267: Testing the Applicability of Leg 208 Sediments for Eolian Analysis. Proc. Ocean Drill. Progr. Sci. Results 2006, 1-13. [CrossRef]

54. Folk, R.L. Petrology of Sedimentary Rocks; Hemphill's Bookstore: Austin, TX, USA, 1974.

55. Reimann, C.; Filzmoser, P.; Garrett, R.; Dutter, R. Statistical Data Analysis Explained: Applied Environmental Statistics with R; Wiley, J., Ed.; British Library: Chichester, UK, 2008; ISBN 978-0-470-98581-6.

56. Mann, A.; de Caritat, P.; Sylvester, G. Degree of Geochemical Similarity (DOGS): A Simple Statistical Method to Quantify and Map Affinity between Samples from Multi-Element Geochemical Data Sets. Aust. J. Earth Sci. 2016, 63. [CrossRef]

57. Taylor, S.R. Abundance of Chemical Elements in the Continental Crust: A New Table. Geochim. Cosmochim. 1964, 28, 1273-1285. [CrossRef]

58. Andrews-Jones, D. The Application of Geochemical Techniques to Mineral Exploration. Colo. Sch. Mines Miner. Ind. Bull. 1968, 11, $1-31$.

59. Glover, E.D. Characterization of a Marine Birnessite. Am. Mineral. 1977, 62, 278-285.

60. Lonsdale, P.; Burns, V.M.; Fisk, M. Nodules of Hydrothermal Birnessite in the Caldera of a Young Seamount. J. Geol. 1980, 88, 611-618. [CrossRef]

61. Stoffers, P.; Glasby, G.P.; Frenzel, G. Comparison of the Characteristics of Manganese Micronodules from the Equatorial and South-West Pacific. Tschermaks Min. Petr. Mitt 1984, 33, 1-23. [CrossRef]

62. De Carlo, E.H.; Fraley, C.M. Chemistry and mineralogy of ferromanganese deposits from the equatorial Pacific Ocean. In Geology and Offshore Mineral Resources of the Central Pacific Basin; Circum-Pacific Council for Energy and Mineral Resources Earth Science Series; Keating, B.H., Bolton, B.R., Eds.; Springer-Verlag: New York, NY, USA, 1992; Volume 14, pp. $247-260$.

63. Post, J.E. Manganese Oxide Minerals: Crystal Structures and Economic and environmental Significance. Proc. Natl. Acad. Sci. USA 1999, 96, 3447-3454. [CrossRef]

64. Corliss, J.B.; Lyle, M.; Dymond, J.; Crane, K. The Chemistry of Hydrothermal Mounds near the Galapagos Rift. Earth Planet. Sci. Lett. 1978, 40, 12-24. [CrossRef]

65. Mukhopadhyay, R.; Ghosh, A.K.; Iyer, S.D. The Indian Ocean Nodule Field, 2nd ed.; Elsevier: Amsterdam, The Netherlands, 2018.

66. Marienfeld, P.; Marchig, V. Indications of Hydrothermal Activity at the Chile Ridge Spreading Centre. Mar. Geol. 1992, 105, 241-252. [CrossRef]

67. Banakar, V.K.; Pattan, J.N.; Mudholkar, A.V. Palaeoceanographic Conditions during the Formation of a Ferromanganese Crust from the Afanasiy-Nikitin Seamount, North Central Indian Ocean: Geochemical Evidence. Mar. Geol. 1997, 136, $299-315$. [CrossRef]

68. ISA International Seabed Authority. A Geological Model of Polymetallic Nodule Deposits in the Clarion-Clipperton Fracture Zone; ISA Technical Study; ISA: Kingston, Jamaica, 2010; Volume 6, pp. 1-75.

69. Peckmann, J.; Thiel, V. Carbon Cycling at Ancient Methane-Seeps. Chem. Geol. 2004, 205, 443-467. [CrossRef]

70. Mazzini, A.; Aloisi, G.; Akhmanov, G.G.; Parnell, J.; Cronin, B.T.; Murphy, P. Integrated Petrographic and Geochemical Record of Hydrocarbon Seepage on the Vøring Plateau. J. Geol. Soc. 2005, 162, 815-827. [CrossRef]

71. Merinero, R. Procesos Mineralógicos y Geoquímicos En Chimeneas Submarinas de Carbonatos Metanógenos Del Golfo de Cádiz: Biogeomarcadores Framboidales de Sulfuros y Oxihidróxidos de Hierro. Ph.D. Thesis, Universidad Complutense de Madrid, Madrid, Spain, 2008.

72. Buffett, B.; Archer, D. Global Inventory of Methane Clathrate: Sensitivity to Changes in the Deep Ocean. Earth Planet. Sci. Lett. 2004, 227, 185-199. [CrossRef]

73. Merinero, R.; Lunar, R.; Martínez, J. Carbonatos Metanógenos y Pirita Framboidal Autigénica: Geomarcadores de La Actividad de Organismos Quimiosintéticos En El Golfo de Cádiz. Rev. Soc. Española Miner. 2010, 12, $29-37$.

74. Palacios, C.M.; Bertens, A.; Ruz, L. Polymetallic Skarn Mineralization at El Toqui, Aysén Province, Southern Chile. Zbl. Geol. Palaeontol. 1994, 1, 723-737.

75. Nagle, F.; Fink, L.K.; Boström, K.; Stipp, J.J. Copper in Pillow Basalts from La Desirade, Lesser Antilles Island Arc. Earth Planet. Sci. Lett. 1973, 19, 193-197. [CrossRef]

76. Abrajano, T.A.; Pasteris, J.D. Zambales Ophiolite, Philippines, I. Geology and Petrology of the Critical Zone of the Acoje Massif. Tectonophysics 1989, 168, 65-100. [CrossRef]

77. Puchelt, H.; Prichard, H.; Berner, Z.; Maynard, J. Sulfide Mineralogy, Sulfur Content and Sulfur Isotope Composition of Mafic and Ultramafic Rocks from Leg 147. Proc. Ocean Drill. Progr. Sci. Results 1996, 147, 91-101.

78. Dekov, V.M.; Rouxel, O.; Asael, D.; Hålenius, U.; Munnik, F. Native Cu from the Oceanic Crust: Isotopic Insights into Native Metal Origin. Chem. Geol. 2013, 359, 136-149. [CrossRef]

79. Jenkyns, H.C. Sediments and Sedimentary History of the Manihiki Plateau, South Pacific Ocean. Initial Rep. DSDP 1976, 34, 873-890. 
80. Knox, R.W.O. Note on the Occurrence of Native Copper in Tertiary Nannofossil Oozes from the Goban Spur (Hole 550). Initial Rep. DSDP 1985, 80, 851-852.

81. Marchig, V.; Erzinger, J.; Heinze, P.-M. Sediment in the Black Smoker Area of the East Pacific Rise (18.5 ${ }^{\circ}$ S). Earth Planet. Sci. Lett. 1986, 79, 93-106. [CrossRef]

82. Dekov, V.M.; Damyanov, Z.K.; Kamenov, G.D.; Bonev, I.K.; Bogdanov, K.B. Native Copper and A-Copper-Zinc in Sediments from the TAG Hydrothermal Field (Mid-Atlantic Ridge, $26^{\circ} \mathrm{N}$ ): Nature and Origin. Mar. Geol. 1999, 161, 229-245. [CrossRef]

83. Kamran, A.; Schneider, D.; Roddatis, V.; Thiel, V.; Hoppert, M. Formation of Siderite in Microbial Microcosms Derived from a Marine Sediment. Geomicrobiol. J. 2020, 37, 475-485. [CrossRef]

84. Yang, X.; Zhang, Z.; Santosh, M.; Duan, S.; Liang, T. Anoxic to Suboxic Mesoproterozoic Ocean: Evidence from Iron Isotope and Geochemistry of Siderite in the Banded Iron Formations from North Qilian, NW China. Precambrian Res. 2018, 307, 115-124. [CrossRef]

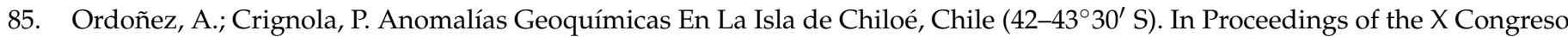
Geológico Chileno, Concepción, Chile, 6-10 October 2003. 